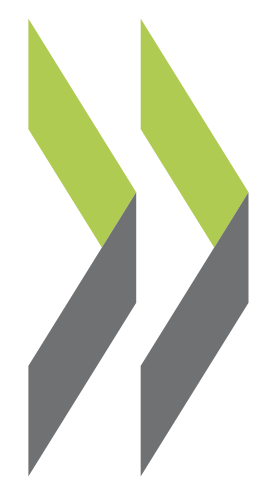

OECD Economics Department Working Papers No. 986

\title{
Tackling Turkey's External and Domestic \\ Macroeconomic Imbalances
}

\section{Oliver Röhn,}

Rauf Gönenç,

Vincent Koen,

\section{Ramazan Karaşahin}

https://dx.doi.org/10.1787/5k92smvqbb8v-en 
Organisation de Coopération et de Développement Économiques

Organisation for Economic Co-operation and Development

13-Sep-2012

ECONOMICS DEPARTMENT

English - Or. English

TACKLING TURKEY'S EXTERNAL AND DOMESTIC MACROECONOMIC IMBALANCES

ECONOMICS DEPARTMENT WORKING PAPERS No. 986

By Oliver Röhn, Rauf Gönenç, Vincent Koen and Ramazan Karaşahin

All Economics Department Working Papers are available through OECD's Internet website at http://www.oecd.org/eco/workingpapers

JT03326208

Complete document available on OLIS in its original format

This document and any map included herein are without prejudice to the status of or sovereignty over any territory, to the delimitation of international frontiers and boundaries and to the name of any territory, city or area. 


\section{ABSTRACT/RÉSUMÉ}

\section{Tackling Turkey's external and domestic macroeconomic imbalances}

Effective macroeconomic and structural policies helped Turkey bounce back quickly and strongly from the global crisis, with annual growth averaging close to $9 \%$ over 2010-11. However, the current account deficit widened to around $10 \%$ of GDP in 2011 and consumer price inflation rose to over $10 \%$. The external deficit, which is far too large for comfort, is a source of vulnerability. So is high inflation, even if it partly reflects transient factors. These imbalances signal competitiveness problems and a dearth of domestic saving. They need to be addressed using both macroeconomic and structural policy levers. Monetary policy has recently tried to reduce the volatility of capital flows but inflation has been high and volatile. The inflation target needs to be given greater prominence. The fiscal stance remains broadly appropriate but could be tighter, if warranted, to complement monetary restraint and help keep the real exchange rate on a sustainable path. More balanced growth through strengthened competitiveness and greater private saving calls inter alia for increased labour force participation, accelerated formalisation, stronger productivity growth, improvements in financial literacy and a more attractive menu of saving instruments. Improvements in the business environment would spur foreign direct investment, making for healthier funding of the external gap.

This Working Paper relates to the 2012 OECD Economic Survey of Turkey

(www.oecd.org/eco/surveys/turkey).

JEL classification: E2; E3; E44; E52; E62; F32; F41; G18; O11; O52.

Keywords: Turkey; current account; competitiveness; saving; monetary policy; fiscal policy; financial market policy.

$* * * * * * * *$

\section{Corriger les déséquilibres macroéconomiques externes et internes en Turquie}

Des politiques macroéconomiques et structurelles efficaces ont permis à l'économie turque de sortir rapidement de la crise mondiale, avec une croissance annuelle moyenne proche de $9 \%$ en 2010-11. Néanmoins, le déficit de la balance des opérations courantes s'est creusé pour atteindre près de $10 \%$ du PIB en 2011 , alors que la hausse des prix à la consommation a dépassé les $10 \%$. Le déficit extérieur constitue une source de vulnérabilité. Cela vaut également pour le taux d'inflation, même s'il est en partie imputable à des facteurs transitoires. Ces déséquilibres sont révélateurs de problèmes de compétitivité et d'une pénurie d'épargne intérieure. Il faut y remédier en s'appuyant à la fois sur les politiques macroéconomiques et structurelles. Les autorités monétaires se sont efforcées de réduire l'instabilité des flux de capitaux, mais l'inflation est restée élevée et fluctuante. Une plus grande importance doit être attachée à l'objectif d'inflation. L'orientation budgétaire reste à peu près satisfaisante, mais pourrait devoir être resserrée, au besoin, pour compléter la politique de restriction monétaire et contribuer au maintien du taux de change réel sur une trajectoire viable. Une croissance plus équilibrée reposant sur une compétitivité renforcée et une augmentation de l'épargne passe, entre autres, par une hausse du taux d'activité, la réduction de l'économie informelle, la croissance de la productivité, l'éducation financière et la mise en place d'une palette plus attrayante d'instruments d'épargne. Une amélioration de l'environnement des entreprises stimulerait l'investissement direct étranger, ce qui permettrait une couverture plus saine des besoins de financement extérieur.

Ce Document de travail se rapporte à l'Étude économique de l'OCDE de la Turquie, 2012 (www.oecd.org/eco/surveys/turkey).

Classification JEL : E2 ; E3 ; E44 ; E52 ; E62 ; F32 ; F41 ; G18 ; O11 ; O52.

Mots clés: Turquie ; compétitivité ; épargne ; politique monétaire ; politique budgétaire ; politique des marchés financiers.

You can copy, download or print OECD content for your own use, and you can include excerpts from OECD publications, databases and multimedia products in your own documents, presentations, blogs, websites and teaching materials, provided that suitable acknowledgment of OECD as source and copyright owner is given. All requests for commercial use and translation rights should be submitted to rights@oecd.org 


\section{TABLE OF CONTENTS}

TACKLING TURKEY'S EXTERNAL AND DOMESTIC MACROECONOMIC IMBALANCES .......... 5

Bringing down the current account deficit and financing it better .......................................................... 5

Key features of Turkey's current account developments ..................................................................... 7

Accumulated competitiveness losses led to a marked worsening of the trade balance .......................... 9

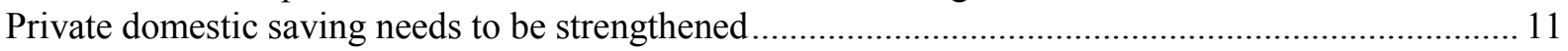

The financing structure of the current account weakened after the crisis............................................. 15

How does the current account deficit compare to benchmarks? ...................................................... 18

Policy options to reduce the current account deficit and inflation ........................................................ 19

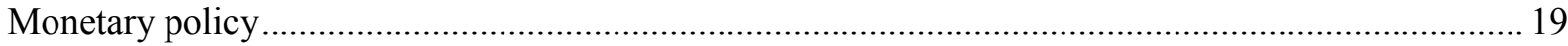

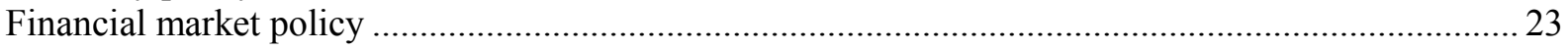

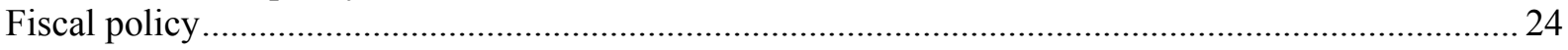

Policies to increase household saving and to channel them into productive uses ............................... 26

Policies to improve the financing of the current account and decrease financial vulnerability.............27

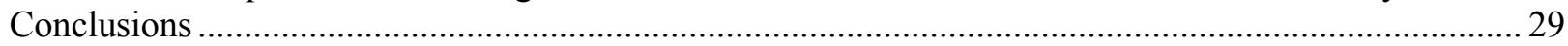

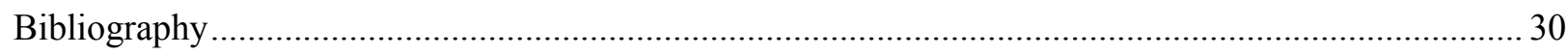

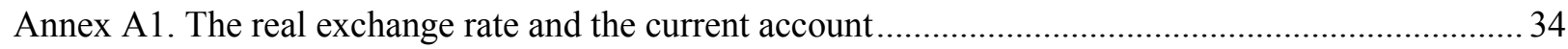

Annex A2. Empirical analysis of inflation expectations in Turkey ........................................................ 36

\section{Tables}

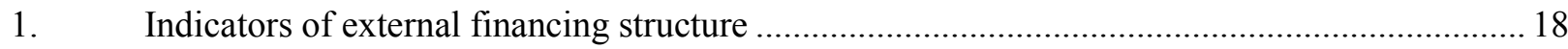

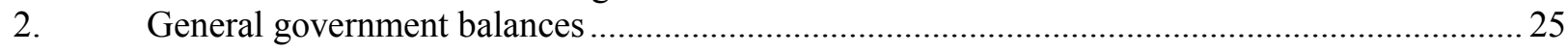

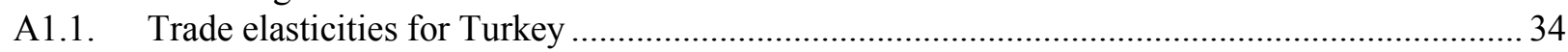

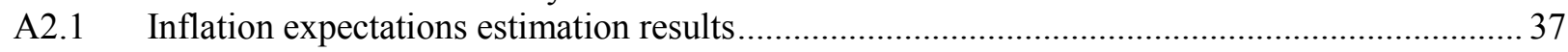

\section{Figures}

1. Turkey's current account deficit has reached unprecedented levels......................................... 6

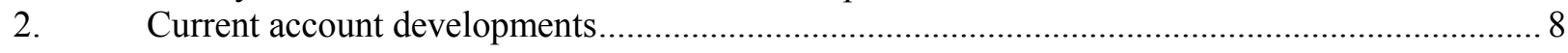

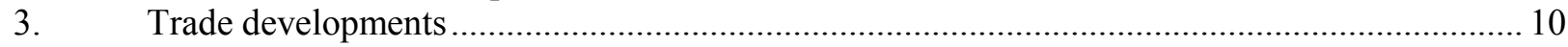

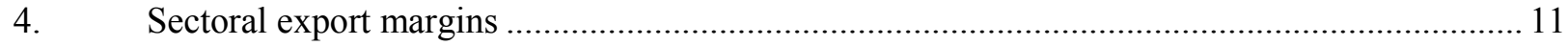

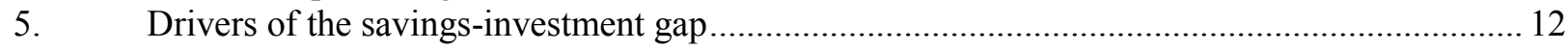

6. The financing of the current account has worsened after the crisis .......................................... 16

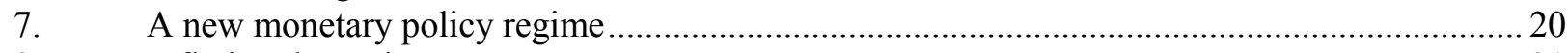

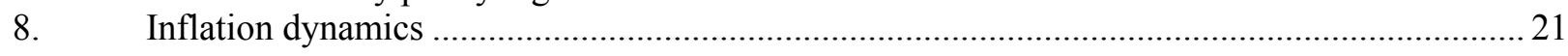

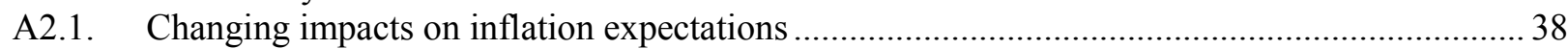

\section{Boxes}

Box 1. Current account imbalances: international experience and theoretical considerations.................... 7

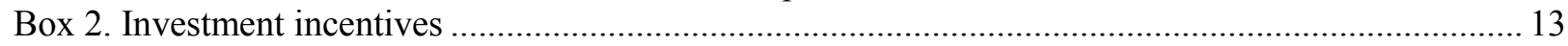

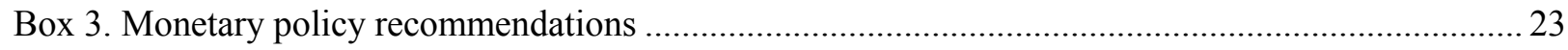

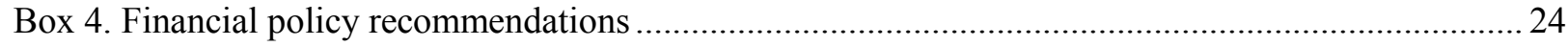

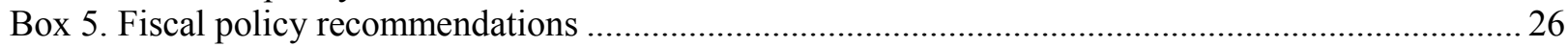

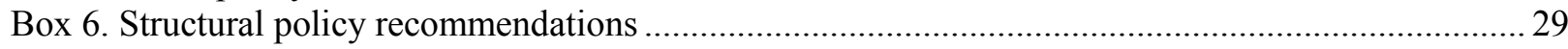


ECO/WKP(2012)63 
ECO/WKP(2012)63

\title{
TACKLING TURKEY'S EXTERNAL AND DOMESTIC MACROECONOMIC IMBALANCES
}

\author{
By Oliver Röhn, Rauf Gönenç, Vincent Koen and Ramazan Karaşahin ${ }^{1}$
}

The impact of the global crisis was severe for Turkey, but domestic demand recovered swiftly and growth reached $9.2 \%$ in 2010 and $8.5 \%$ in 2011 . However, in the process, significant economic tensions arose. With estimated slack shrinking fast, consumer price inflation rose to over $10 \%$ by December 2011 , almost twice the target rate. At the same time, the current account deficit widened to $11 \%$ of GDP in the first quarter of 2011, a historically unprecedented level. While the current account gap and inflation have started to come down since, both remain above comfort levels.

This paper discusses the underlying causes of these imbalances, which include both the macroeconomic policy stance but also and crucially a range of structural factors. The paper then turns to the policies that can help mitigate these imbalances and achieve more balanced growth. Structural policies to reform the labour market, to step up formalisation, and to boost productivity are also indispensable to durably improve the current account and help lower inflation, and are discussed in detail in Gönenç et al. (2012).

\section{Bringing down the current account deficit and financing it better}

Turkey's current account deficit reached 9.9\% of GDP in 2011 (Figure 1). In absolute US dollar terms Turkey recorded the second-largest current account deficit in 2011 among all OECD countries. With domestic demand slowing since mid-2011, the current account deficit is narrowing. Even so, it is on course to remain large for some time. A substantial dependence on foreign financing leaves an economy vulnerable to a slowdown in capital inflows with potentially negative consequences for financial stability and growth. In addition, the financing structure of the external deficit also deteriorated after the crisis, with a higher reliance on short-term bank loans, though it began to improve in 2011. Nevertheless, short-term capital inflows continue to play a large role in external financing. With financial market tensions lingering in the euro area, banks in developed countries facing higher capital requirements and more generally uncertainty about the global economic outlook, external financing conditions will remain strained. Accordingly, reducing the current account deficit through a rebalancing of demand is a pressing near-term economic challenge.

1. OECD Economics Department. This paper is a slightly updated version of a chapter from the $O E C D$ Economic Survey of Turkey, which was published in July 2012 under the authority of the Economic and Development Review Committee (EDRC). It has benefitted from background research by Şeref Saygili. The authors thank Andrew Dean and Robert Ford for their valuable comments. Special thanks go to Béatrice Guérard for technical assistance and to Nadine Dufour and Pascal Halim for technical preparation. 
Figure 1. Turkey's current account deficit has reached unprecedented levels

Current account balance as a percentage of GDP
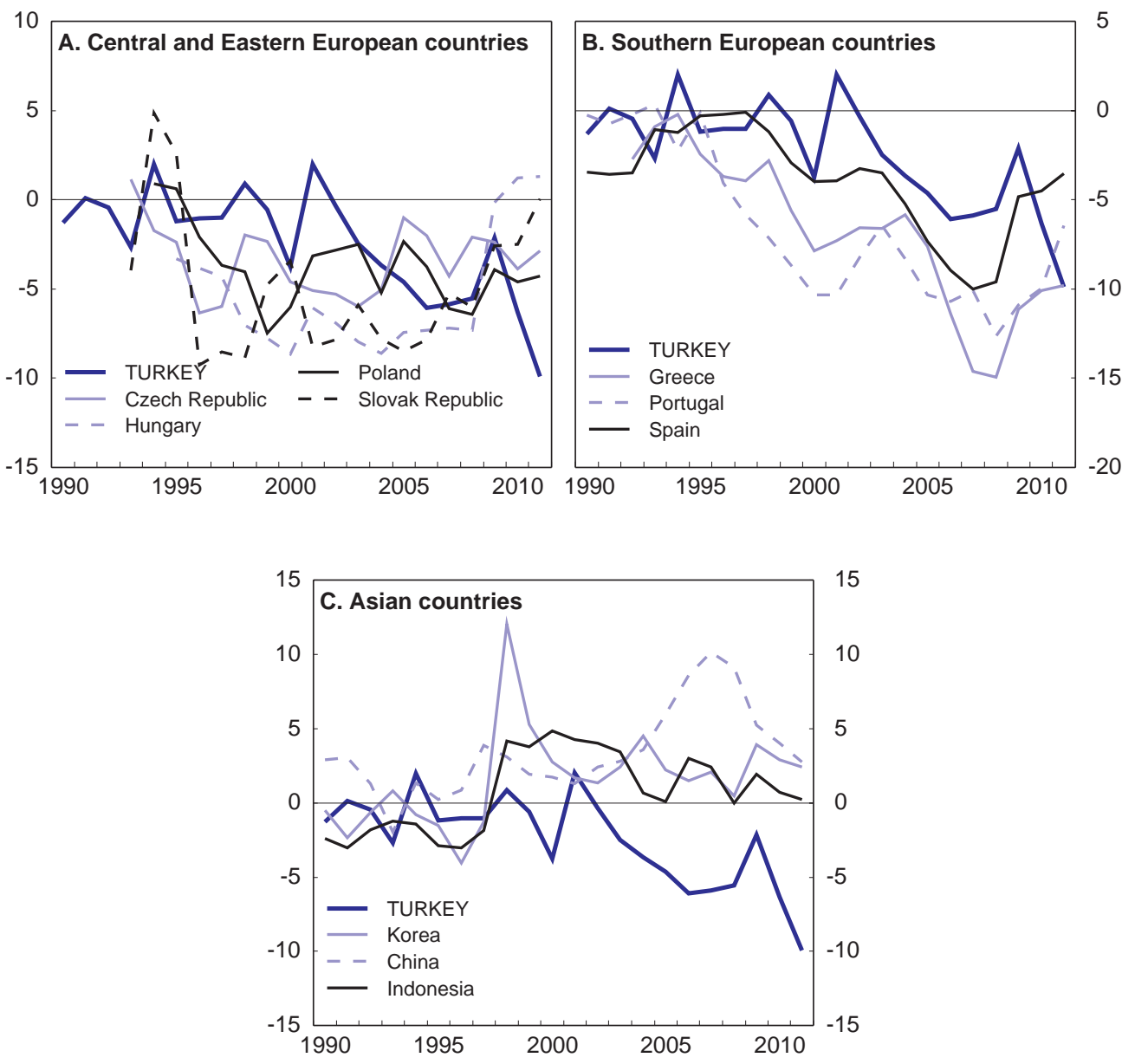

Source: OECD, OECD Economic Outlook database.

This paper suggests that the worsening of Turkey's external balance mainly results from price and labour cost inflation outstripping productivity growth and nominal exchange rate depreciation, thus eroding competitiveness in the tradable sector. This especially affected the formal low-skill labour-intensive manufacturing sector but more recently other sectors too. Additional low-skilled rural migrant labour facing limited formal employment opportunities was mainly absorbed by a new generation of semi-formal and informal enterprises in export-oriented sectors. However, productivity and wage growth is low in these firms, constraining household income and saving. At the same time, overall household saving was low and falling due to macroeconomic stabilisation leading to a fall in interest rates and lower precautionary saving, higher availability of credit, low aggregate employment and the large share of the low-skilled in the population. With investment opportunities aplenty as the economy grew rapidly, this translated into a growing saving-investment gap and consequently a widening current account deficit. 


\section{Box 1. Current account imbalances: international experience and theoretical considerations}

Turkey's sizeable current account deficit is not uncommon for catching-up economies which, given a certain level of political and macroeconomic stability as well as security of property rights, provide ample investment opportunities and high returns for foreign investors. For instance, new EU member countries in Central and Eastern Europe have experienced deficits of similar magnitude as have southern peripheral euro area countries. Recent history has shown that in many cases these imbalances, driven by continuously deteriorating competitiveness as well as asset and credit booms, were unsustainable (Atoyan, 2010). The external balance has improved since the crisis in almost all of these countries, partly due to cyclical weakness, while that of Turkey deteriorated to a level not seen before the crisis. In contrast to these catching-up economies, many emerging Asian countries, after running external deficits before the $1997 / 98$ crisis, combined rapid growth with sizeable current account surpluses on the back of an export-led growth strategy.

Normative assessments of external imbalances are generally difficult as they can arise for "good" or "bad" reasons (Blanchard and Milesi-Ferretti, 2012). On the one hand, external imbalances can be the result of utilitymaximising behaviour in the absence of distortions and reflect the optimal allocation of capital across time and space. On this score, demographic factors or strong economic prospects, as in Turkey, would be relevant. On the other hand, deficits can reflect domestic market distortions. For example, deficient financial regulation can affect the quality of financial intermediation and spur asset and credit booms, or labour market distortions might lead to low employment rates and thus low household income and saving. These distortions should be removed, first and foremost for efficiency and welfare reasons, but a reduction in imbalances can be a welcome side effect. Finally, good reasons for current account imbalances can interact with distortions and lead to inefficient outcomes and increased risk. For example temporary but persistent capital inflows and ensuing currency appreciation can lead to a crowding-out of the tradable manufacturing sector which is more difficult to reverse the more financially constrained the sector is (Caballero and Lorenzoni, 2007).

Irrespective of the underlying causes of external deficits, they imperil the sustainability of growth if they reach a substantial size, calling for policy intervention. In addition, if the country is large enough and has strong financial linkages to other countries, thus constituting a systemic risk, policy attention is warranted from a multilateral perspective. In the case of Turkey, however, financial linkages are still limited and spillovers to other OECD countries from a potential domestic financial crisis would be unlikely to be large even though some of the neighbouring nonOECD countries might be adversely affected.

\section{Key features of Turkey's current account developments}

Turkey's current account deficit hovered around 1\% of GDP during much of the 1980s and 1990s. A more sizeable external imbalance started to emerge only after the financial crisis of 2001, when Turkey experienced strong growth, thanks to important reforms to strengthen its macroeconomic policy framework and financial sector. Spells of current account deterioration have been characterised by $i$ ) strong creditfinanced, domestic demand driven growth, ii) sizeable capital inflows, iii) real exchange rate appreciation and iv) increasing import penetration (Figure 2). These episodes were interrupted by short periods of rebalancing driven by capital outflows and sharp nominal depreciation largely due to external factors, especially global financial turmoil. Despite these nominal depreciations, price and cost competitiveness have worsened over the past decade.

Developments after the outbreak of the global crisis fit this pattern quite well, but with two important differences. First, the deterioration of the current account has been much starker: the deficit went from $0.5 \%$ of GDP in 2009 Q2 to $11 \%$ in $2011 \mathrm{Q} 1$, partly due to oil price increases and cyclical asymmetries, since Turkey recovered far more strongly from the financial crisis than most other OECD economies. Loose monetary conditions in many of Turkey's partner countries fuelled a sharp increase in capital inflows which may have contributed to exceptionally strong domestic credit growth. At the same time, demand for Turkish exports, in particular in the European Union, Turkey's main export market, remained subdued. But as discussed below, competitiveness losses that had accumulated over the previous decade and that were not entirely reversed by the sharp depreciation during the financial crisis, also contributed to the strong deterioration of the current account. 
Figure 2. Current account developments
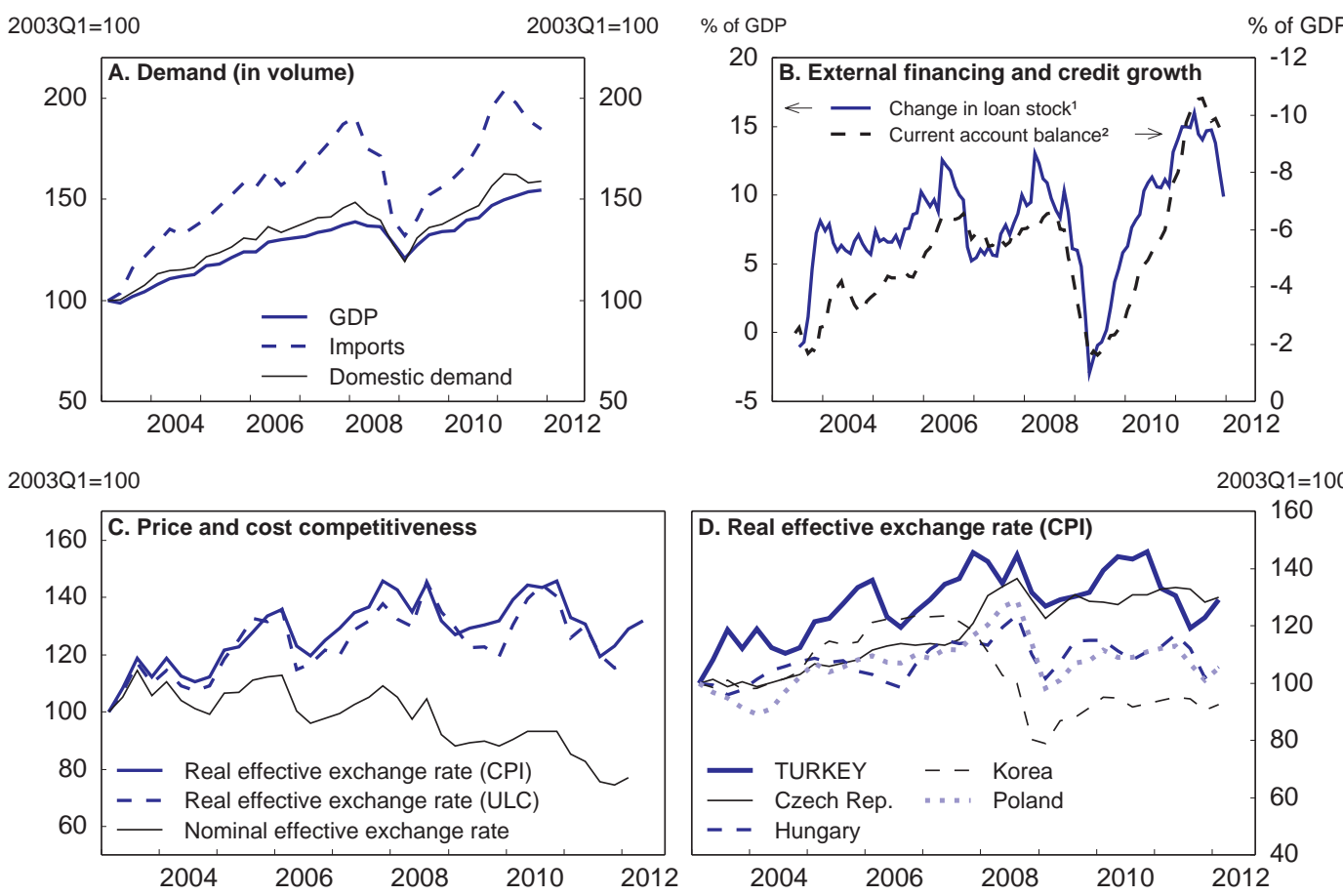

BIn USD
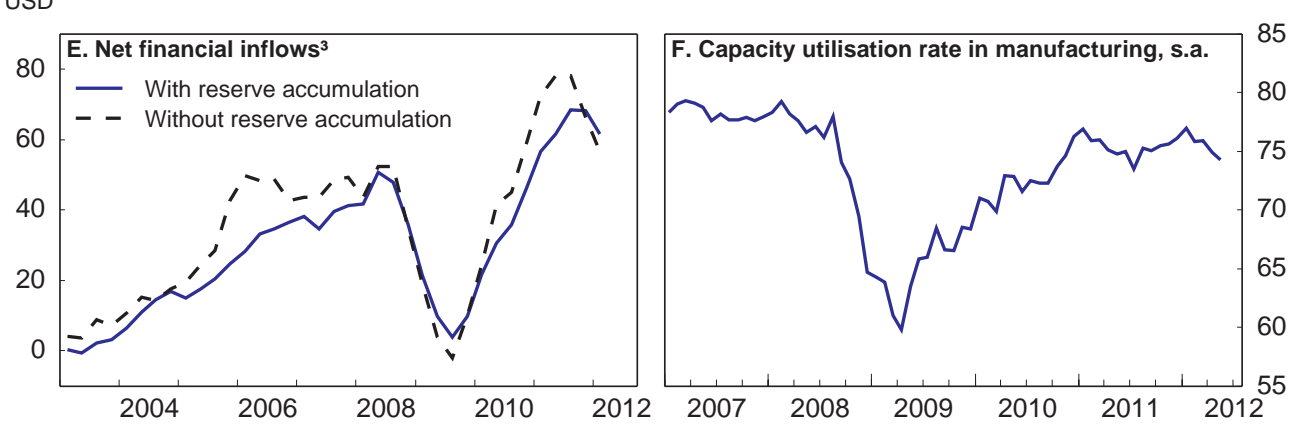

1. Net 6-month change in the total loan stock as a percentage of 6-month rolling cumulative GDP.

2. 6-month rolling cumulative current account balance as a percentage of 6-month rolling cumulative GDP. Monthly GDP figures are approximated using the industrial production index.

3. 4-quarter rolling sum.

Source: Central Bank of Republic of Turkey; OECD, OECD Economic Outlook database; OECD, Main Economic Indicators database; IMF, International Financial Statistics.

Second, the rebalancing from domestic to external demand observed since the second half of 2011 has so far been gradual and not driven by an abrupt contraction in activity, unlike during the global financial crisis. Monetary and financial policy contributed to this gradual rebalancing through a mix of mostly unorthodox measures (see below). However, this rebalancing might prove difficult to maintain for at least two reasons: $i$ ) the substantial nominal depreciation in 2011 has fed through to domestic prices and was partly reversed in early 2012, eroding some of the initial gains in competitiveness; and ii) if global financing conditions worsen, triggering capital outflows, restoring external equilibrium might require a sharp slowdown in domestic demand and import growth. 


\section{Accumulated competitiveness losses led to a marked worsening of the trade balance}

The current account deterioration since the beginning of the 2000s largely reflects that of the trade balance (Figure 3A). Important drivers of trade developments are price and non-price competitiveness as well as domestic and external demand conditions (see Annex A1). Differences between domestic and external demand conditions have contributed to the rising trade deficit, in particular after the crisis. However, thanks to quality improvements and product innovations, non-price competitiveness has tended to improve, as documented in a previous Economic Survey (OECD, 2008). Nevertheless, price competitiveness remains key, all the more so given the recent growth of more price-sensitive lowtechnology industries. The price competitiveness of Turkey's tradable sector has come under pressure since the early 2000s owing to sizeable inflation differentials with trading partners. Nominal labour costs per unit have also run ahead of those in partner countries, due to widespread wage indexation in the formal sector and insufficient labour productivity growth. Consequently the real exchange rate, both in CPI and unit labour cost terms, appreciated significantly notwithstanding short bouts of sharp depreciation driven by the nominal exchange rate in times of global financial turmoil. Cumulatively, the real exchange rate appreciated by $40-45 \%$ between early 2003 and late 2010 . It then weakened by about $15-20 \%$ until the second half of 2011 before starting to appreciate again. Some estimates of the equilibrium real exchange rate for Turkey suggest that it may have been still overvalued in the fall of 2011 (IMF, 2012; Cline and Williamson, 2011). This evidence, in combination with high minimum wages and costly labour market rules in comparison with other OECD and emerging economies as analysed in previous Surveys (OECD, 2008, 2010), points to a significant competitiveness gap in Turkey's tradable sector.

The periods of widening competitiveness gap have seen rising import penetration, and vice versa. However, as Turkey primarily imports raw materials and intermediate goods, part of the rise in import penetration reflects a more global trend towards integration into vertically-integrated global production chains, as in many other OECD countries. As Turkey's import penetration is still below the OECD average, this trend might endure (Figure $3 \mathrm{~B}$ and $\mathrm{C}$ ).

Another factor that may contribute to a limited responsiveness of total imports to improvements in competitiveness in the short to medium term is Turkey's large dependence on energy imports. While net energy imports only explain part of the post-crisis deterioration in the current account, they accounted for about half of the current account deficit in $2011 .^{2}$ Dependence on energy and in particular fossil-fuel imports at least partly reflects fundamental factors such as a lack of natural resources and high energy imports may therefore be a manifestation of a comparative disadvantage. However, energy price controls and hence departures from cost-based pricing may have led to inefficiencies in the use of energy inputs. In addition, potential appears to exist to substitute energy imports through domestic sources (e.g. hydro, wind, thermal and nuclear power). This, however, requires further efforts to promote efficiency and competition in the energy sector. Even if structural reforms promoting more efficient consumption and production of energy take time, their implementation is crucial to reduce energy imports and the current account deficit. As experience has shown, in particular in Asia, substantial current account surpluses are compatible with large net energy imports. For this to happen, however, the competitiveness of the export sector needs to be durably improved.

2. According to CBRT estimates, each $\$ 10$ increase in the oil price increases the current account deficit by $0.5 \%$ of GDP. 
Figure 3. Trade developments
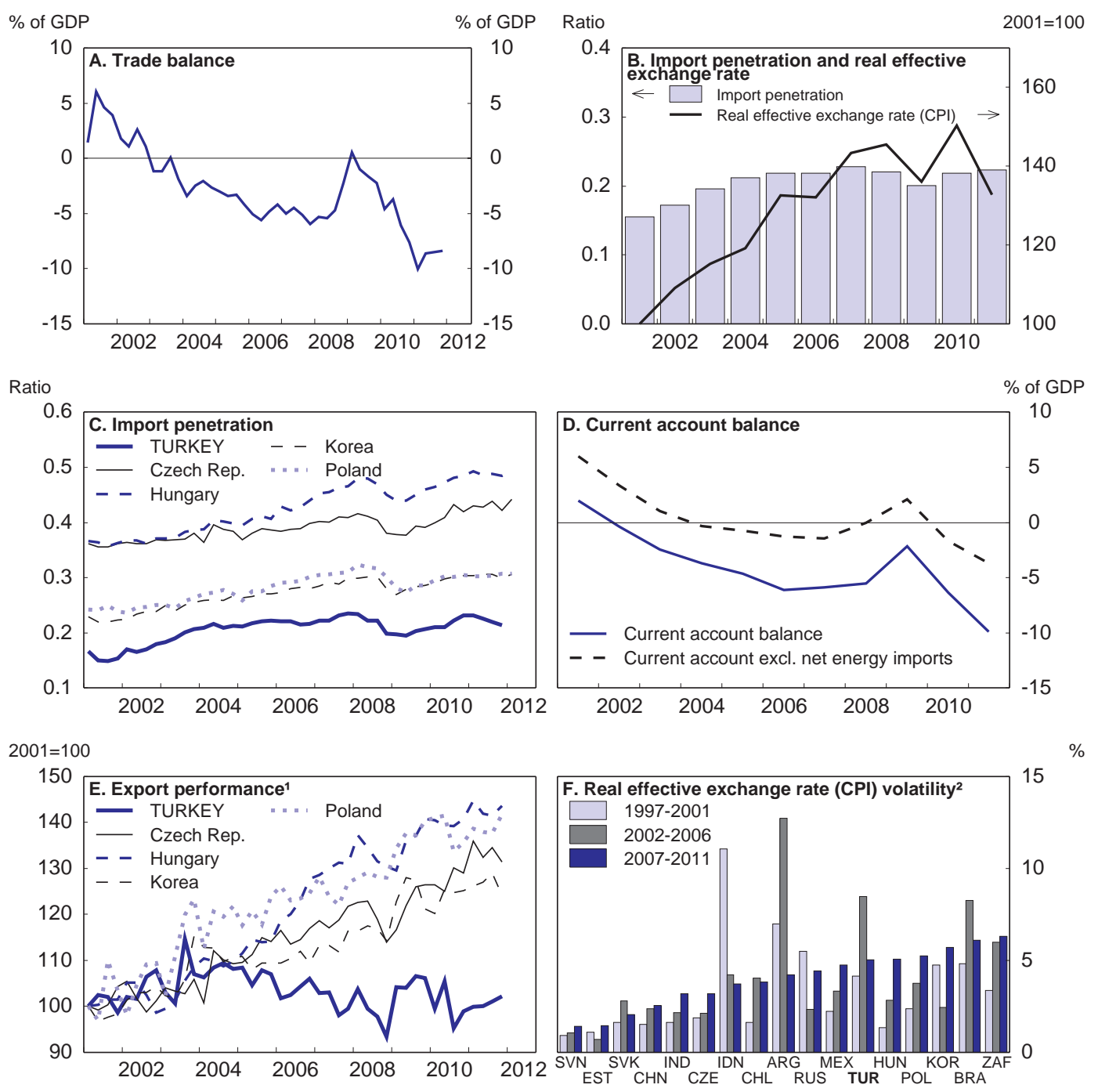

1. "Export performance" measures export competitiveness and is calculated as actual volume growth in exports relative to the growth of the country's export market, which represents the potential export growth for a country assuming that its market shares remain unchanged.

2. Standard deviation of monthly growth rate.

Source: Turkish Statistical Institute; OECD, OECD Economic Outlook database.

On the export side, aggregate measures of Turkey's export market share have been volatile over the past ten years, without a clear up- or downward trend, whereas several of Turkey's emerging market peers gained market share (Figure 3E). However, this aggregate measure masks important structural changes within the manufacturing export sector analysed in previous Economic Surveys (OECD, 2008, 2010): while traditional low-tech formal sectors relying heavily on low-skilled labour (textiles, clothing, leather) were hardest hit by the squeeze in price competitiveness during the 2000s, new medium-tech sectors (cars, white goods, industrial machinery) could partly offset nominal cost pressures and on average strongly increased production, exports and employment (Figure 4). The latter sectors benefitted from their higher capital intensity in combination with a general trend decline in capital costs, quality improvements which allowed them to set higher price mark-ups, higher productivity growth and a shift towards imported intermediate goods. 
In addition, a new generation of export-oriented manufacturing firms sprung up in previously nonindustrialised, low-income regions. They rely mainly on low-skilled labour, but maintained competitiveness by often using informal and semi-formal labour contracts to circumvent high minimum wages, wage pressures and formal-sector rigidities. However, productivity growth in these new sectors is low (see Gönenç et al., 2012), leaving limited room for wage growth if competitiveness is to be preserved, with negative repercussions on labour income and household saving, as discussed in the next section.

Figure 4. Sectoral export margins

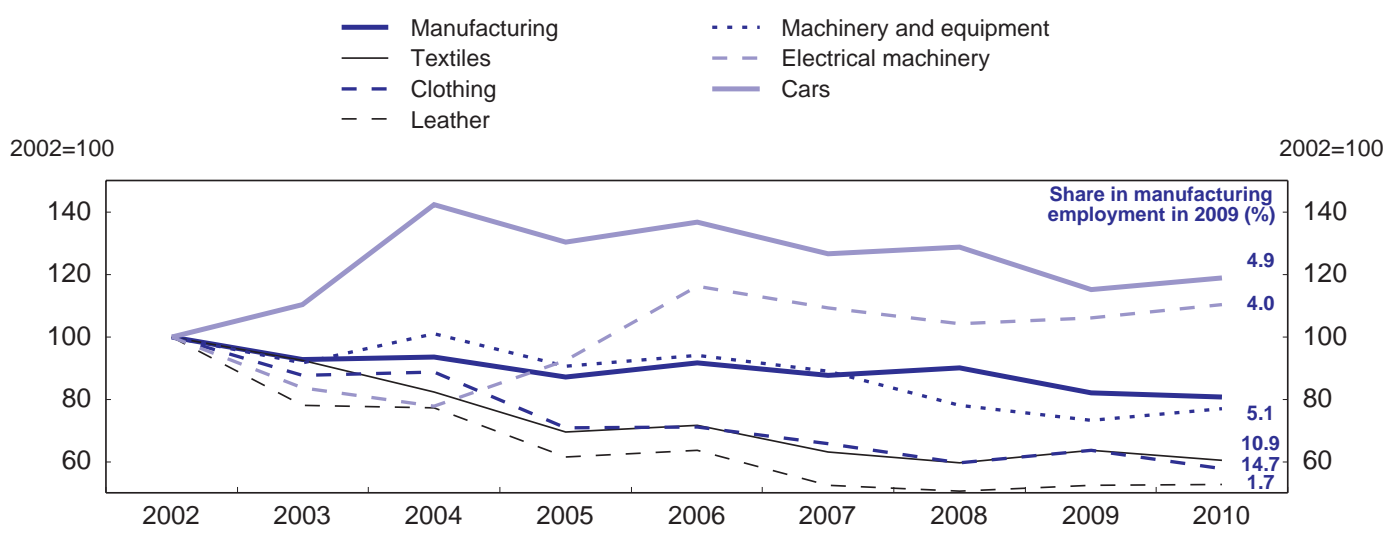

Note: Ratio of export prices in national currency to unit labour costs in national currency, which can be interpreted as a measure of margins encompassing both price and non-price competitiveness (see Yilmaz and Gönenç, 2008).

Source: OECD estimates.

Looking ahead, improvements in the trade balance will mainly depend on Turkey's ability to boost exports. With demand from Europe likely subdued in the short to medium term, one way to do so is by diversifying into new fast-growing export markets. Efforts in this direction are already under way: Turkish exporters have increasingly penetrated new markets in the Middle East but also in Asia and the Americas, Özlale and Cunedioglu, 2011). Nevertheless, given its specialisation in low- to medium-tech products, Turkey is likely to continue to face low-cost competition also in new markets. This points to the importance of striving to improve competitiveness. Future competitiveness is shaped by: $i$ ) nominal labour cost developments; ii) productivity growth; and iii) nominal exchange rates. Nominal exchange rate pressures depend on capital inflows as well as monetary policy settings. Labour costs are influenced by inflation dynamics as well as structural reforms in the labour market. Finally productivity growth depends notably on the ability to shift resources into the formal sector, competition in product markets and quality improvements in human capital (Gönenç et al., 2012).

In addition to developments in competitiveness, investment in the tradable sector and hence the future ability to generate export revenues or reduce import bills may also be influenced by the volatility of the real exchange (Hausmann and Rigobon, 2003). Volatile real exchange rates make production in the tradable sector more risky relative to non-tradables. While the volatility of Turkey's real exchange rate has decreased since the mid-2000s, it remains higher than in many other emerging economies (Figure 3F). Further declines in exchange rate volatility would strengthen the tradable sector.

\section{Private domestic saving needs to be strengthened}

The corollary of the widening trade deficit was the opening-up of a domestic saving-investment gap from the beginning of the 2000s. This gap reflected both a secular decline in private saving and a surge in private investment (Figure 5A). In contrast to private saving, public deficits turned into surpluses in the 2000 s thanks to strong consolidation efforts. This increase only partly offset the drop in private saving. In the context of the global crisis, public dissaving resumed, as fiscal policy provided a stimulus (OECD, 
2010). However, in 2010-11 the latter was largely withdrawn. In contrast to private investment, public investment remained relatively stable throughout the entire period and was mainly directed at enhancing transport infrastructure.

Figure 5. Drivers of the saving-investment gap

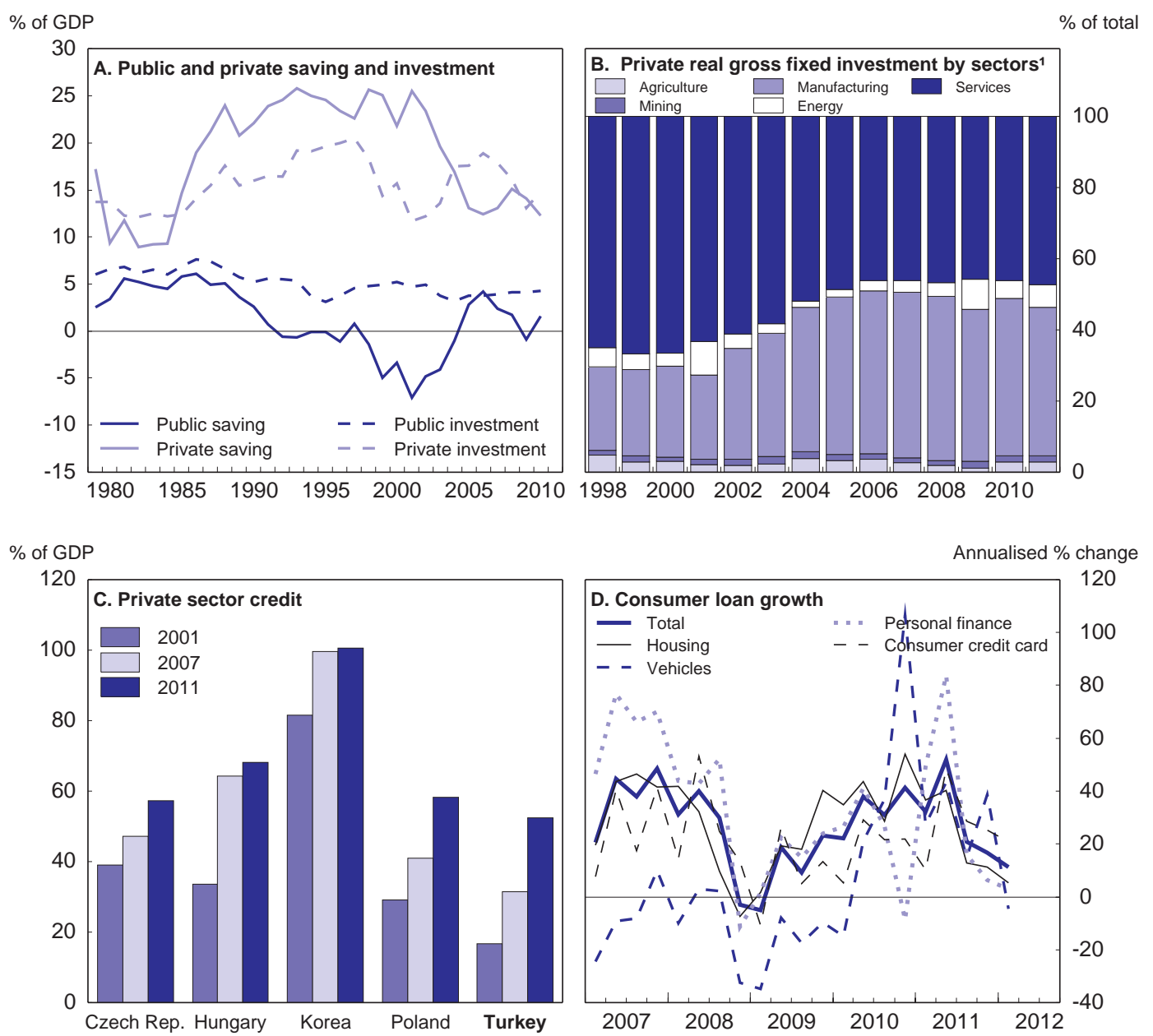

1. Data for 2010 and 2011 are projections.

Source: Ministry of Development; IMF, International Financial Statistics; OECD, OECD Economic Outlook database; Central Bank of the Republic of Turkey.

The surge in private investment can be traced back to major structural and institutional reforms including macroeconomic stabilisation, microeconomic liberalisation and strengthening of the banking sector which led to sharply falling capital costs following the 2000-01 crisis (OECD, 2008, 2010). In addition the government granted regional and horizontal investment incentives and provided public infrastructures (organised industrial zones) especially in previously non-industrial regions. But strong entrepreneurial dynamism also played a role. Investment was mainly driven by machinery and equipment and channelled into manufacturing, suggesting that investment incentives remained high despite competitiveness losses (Figure 5B). However, investment in manufacturing may have been partly used to substitute labour, and investment also largely took place in the new generation of export-oriented manufacturing firms which could circumvent costly labour regulations. Besides manufacturing, investment in transport and communication also expanded strongly. Construction investment only increased 
moderately, ${ }^{3}$ in contrast with the boom experienced in several of the peripheral euro area countries and new EU member states in Central and Eastern Europe. Private investment collapsed during the global crisis but quickly rebounded, largely driven by the same forces as prior to the crisis.

Even so, the investment share in GDP, currently at about $22 \%$, remains lower than in several highperforming Asian countries. This suggests that if anything, investment in Turkey needs to grow faster to sustain GDP and employment growth, and the government recently announced new investment incentives (see Box 2). The new system preserves a number of positive features of the preceding regime: $i$ ) eligible beneficiaries are identified on the basis of explicit criteria and rules, minimising room for administrative discretion; ii) no distinction is made according to firm ownership (public versus private or domestic versus foreign); and iii) no trade protection is involved, in contrast to incentive policies applied in a number of other emerging countries. A stronger emphasis is given to sectoral criteria, with newly defined "strategic sectors" receiving additional incentives. The definition of "strategic sectors" will be rule-based, which should reduce interest group pressures and attempts to "pick winners". Additional safeguards, including the rules of the World Trade Organisation and the provisions of Turkey's Customs Union agreement with the European Union, which includes a "State Aid Commission" evaluating the competitive impacts of incentives, are expected to help minimize any distortions in competition and resource allocation. The new incentive system may increase the saving-investment gap in the short term by encouraging additional investment. However, if the incentives have the intended effects, they might stimulate additional supply capacity in the tradable sector with favourable effects on the trade balance in the longer term.

\section{Box 2. Investment incentives}

A new incentive package was legislated in June 2012 to stimulate domestic and foreign investment in the face of a weak global economy and to encourage additional supply capacity in the tradable sector, which may help increase exports or reduce imports in coming years. It will be applied retrospectively to investments made from January 2012.

This new system is an extended version of the comprehensive existing incentive regime, which went through successive vintages in 2004, 2005 and 2009. In a nutshell, this system granted VAT and customs duty exemptions, employer social security contribution exemptions, corporate or personal income tax concessions and land grants and interest-rate subsidies to investment projects. Eligibility depended on region, sector and size:

- The region was the key criterion. Turkey's 26 NUTS 2 regions were combined into four groups based on economic and social development. Investments in the least developed group ("Level IV") received support of up to $45 \%$ of their initial costs (calculated in nominal values by cumulating the corporate or personal income tax exemptions and social security contribution cuts received during the operational life cycle of a project, as a share of its initial cost). In the more developed group ("Level I"), investments received support of up to $25 \%$ of their initial costs.

- $\quad$ Benefits were differentiated to a lesser extent between sectors and only a few sectors considered in excess supply were excluded.

- Finally, incentives were differentiated by investment size: large investments with initial costs above TL 50 million ( $€ 20$ million) were granted additional corporate tax concessions.

The new regime legislated in June 2012 introduces certain additional features:

- As the earlier groupings were criticized for combining provinces with large development gaps, the new system distinguished six areas instead of four by clustering Turkey's 81 NUTS 3 provinces. Besides, the level of support has been raised.

3. However, there are some concerns about a real estate investment boom in the Istanbul area. 
- $\quad$ "Priority" sectors, which are considered to provide positive externalities for the rest of the economy, receive stronger incentives, irrespective of regional location. These sectors include tourism (investment in cultural and touristic preservation and development areas), mining, railroad and maritime transport, pharmaceuticals, defence (with a minimum investment of TL 20 million ( $€ 9$ million)) and education. They receive the same degree of benefits as those granted in "Region 5" (the second most supported region).

- Newly defined "strategic" sectors will receive additional benefits. The government announced that the sectors where Turkey's dependence on imports is highest (where imports represent more than $50 \%$ of domestic demand) will be eligible. Only projects generating more than $40 \%$ of local value added will be supported.

- "Eligible forms of business organisation", which are expected to provide extra benefits to the economy, will also receive additional benefits. Eligible forms include joint investments between more than five partners (to promote clustering), investments undertaken in organised industrial zones, and mass production of innovative products developed in co-operation with the national science foundation (TUBITAK).

- Additional support will be granted to investments in the least developed region. Most importantly, employer and employee social security contributions and personal income taxes (up to a cap) will be exempted for 10 years, entirely eliminating the labour tax wedge during that period.

How far this new incentive regime will differ in practice from the earlier framework will depend to a large extent on the definition and scope of "strategic" sectors and their additional benefits relative to "non-strategic" sectors.

While data on household saving are not readily available as part of the national accounts, studies point to a pronounced decline in household saving between 2001 and 2008 (World Bank, 2012). Five main reasons can be identified: $i$ ) increased macroeconomic stability reduced precautionary motives for saving; ii) lower real interest rates; iii) improved income prospects; iv) better credit availability, in particular for lower-income households; and v) low and - in the first half of the $2000 \mathrm{~s}$ - declining employment rates. While the first three explanations can be generally seen as welcome developments, the last two deserve further analysis.

Banking sector loans to the private sector had been very low in Turkey before the 2001 crisis. Private credit grew rapidly thereafter, even though it remains low compared to peer countries (Figure 5C and OECD, 2010). Better credit availability led to an increase in purchases of consumer durables (World Bank, 2012). Consumer loan growth bounced back after the crisis and reached a disquieting pace in the first half of 2011, mainly driven by personal finance loans (Figure 5D). This triggered measures by the Central Bank of the Republic of Turkey (CBRT) and the banking regulators (see below), which helped curb consumer loan growth. Non-performing consumer loan ratios of banks fell until the end of 2011 and remain low despite some deterioration since early 2012. Ratios of household interest payments to household disposable income have been falling since the crisis, to around $4.8 \%$ by the end of 2011 . Nevertheless, household financial liability-to-asset ratios have been increasing rapidly albeit from low levels, to around $46 \%$ by the end of 2011 (CBRT, 2012a).

Household saving rates and income are closely correlated in Turkey (World Bank, 2012). Employment rates, in particular those of women, are traditionally low in Turkey and declined in the early 2000 s, translating into a higher share of households that depend only on one income earner and thus reducing the saving potential. Moreover, migration from rural to urban areas increased the already large share of low-skilled in the population looking for work. Formal employment and income prospects for low-skilled deteriorated during the 2000s due to the competitive losses of formal labour-intensive industries (see above) and the growing skill demand in the economy. While part of the low-skilled were absorbed by the informal sector, a sizeable wage gap exists (Baskaya and Hülagü, 2011) and wage growth is on average lower. Given persistently high inflation this has held back real household income, with negative repercussions on the saving potential. Employment rates have been increasing rapidly since the 
crisis, though partly in the form of unpaid rural labour and in low-income activities. Increasing employment rates more durably and with a higher share in the formal sector is an important avenue to lift household income and saving.

There is room to channel existing household savings into more productive uses. A sizeable part of private savings are kept outside of the financial system (see below). This is consistent with the large errors and omissions line in the balance of payments, which tends to expand when external financing conditions worsen. The large share of the informal economy which increases demand for informal, unregistered and anonymous assets may be mainly responsible, but it may also reflect a lack of financial literacy. Additionally, households typically hold a higher share of savings in the form of non-financial assets. This is despite the fact that generally falling inflation and increased stability of the financial sector should have boosted demand for financial assets. A relatively limited choice of alternative saving instruments offered by banks and other financial institutions may be part of the reason. The banking system and other financial institutions could thus help to enhance the productive allocation of long-term household savings by offering a wider variety of saving instruments.

Corporate saving is also low in Turkey, below that in other emerging markets (Bayoumi et al., 2010, World Bank, 2012). Corporate saving tends to be correlated with firm profits and GDP, and productivity growth might be the single most important factors influencing firm profits (André et al., 2007). The relatively low level of corporate saving in Turkey may also be related to the high share of small to medium-sized enterprises (SMEs) that mainly operate in the semi-formal and informal sector. These firms tend to operate below the optimal size to avoid costly administrative burdens and are constrained by limited access to external finance. Thus, policies that tackle the underlying causes of informality such as costly labour market regulations may increase corporate saving.

Firm profitability is also influenced by changes in the real exchange rate, but the effect depends on export- and import-intensities as well as net foreign exchange positions of firms through balance-sheet effects and therefore the economy-wide impact is ambiguous. The World Bank (2012), using Turkish firmlevel data, shows that currency appreciations have reduced net profit margins and saving in large exportintensive firms. Yilmaz and Gönenç (2008) find that average profit margins of labour-intensive manufacturing sectors have been particularly squeezed due to the trend currency appreciation in the run-up to the financial crisis. However, non-tradable sectors tend to be positively affected by appreciation due to lower import prices. Moreover, net foreign exchange liability positions in the non-financial corporate sector are sizeable and have been rising sharply recently (see below) and Kesriyeli et al. (2011) report that real exchange rate appreciation boosts investment and profits for sectors with higher net foreign exchange liabilities in Turkey. Nevertheless, to the extent that tradable goods production is associated with greater technology and skill transfer from abroad than for non-tradables (Rodrik, 2006), a real-depreciationinduced shift from non-tradable to tradable production might improve economy-wide productivity growth and hence corporate saving.

\section{The financing structure of the current account weakened after the crisis}

The sustainability of a country's current account deficit and its financial vulnerability are influenced by the composition of the inflows funding the external gap. Short-term loans and portfolio inflows are usually more prone to sudden reversal while long-term loans and foreign direct investment (FDI) inflows are regarded as more stable. Moreover, debt contracts require regular payments regardless of the borrowers' economic situation whereas equity and FDI inflows are largely state-contingent liabilities and are generally associated with technology and skill transfers. 
Figure 6. The financing of the current account has worsened after the crisis
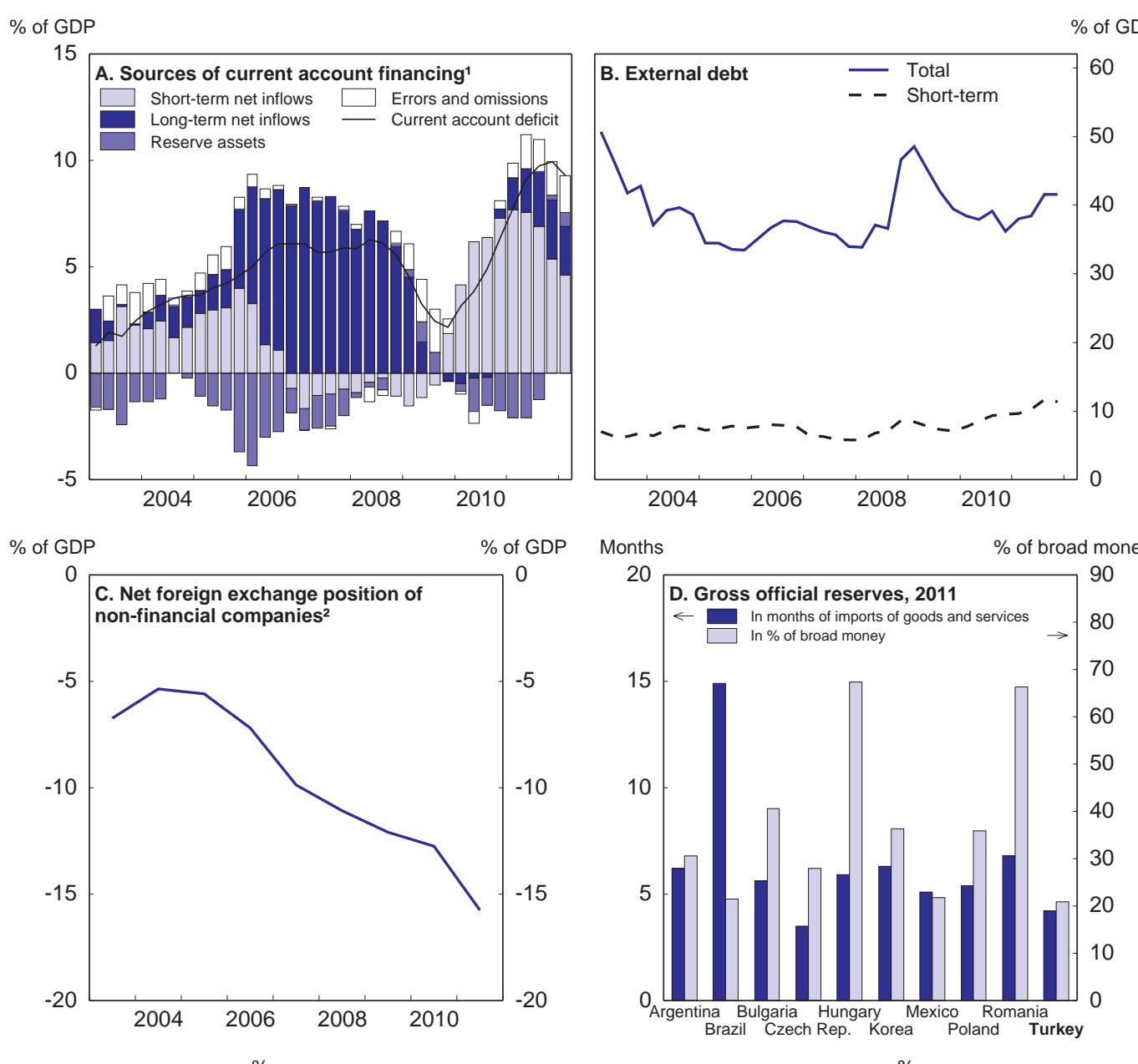

$\%$
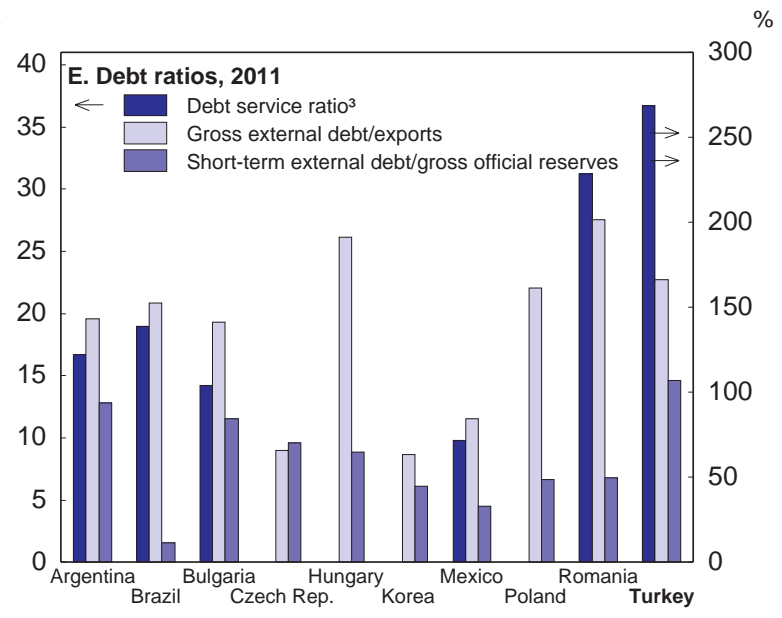

1. Rolling 4-quarter sum as a percentage of moving average GDP. Short-term inflows refer to the sum of portfolio investment and short-term other investment net inflows. Long-term inflows refer to the sum of FDI and long-term other investment net inflows. GDP data for 2012Q1 is projected.

2. Difference between the foreign-currency-denominated assets and liabilities.

3. Total debt service payments in per cent of exports of goods and services. Data for 2010.

Source: IMF, International Financial Statistics; OECD, OECD Economic Outlook database; Undersecretariat of Treasury; Central Bank of the Republic of Turkey; World Bank, Global Development Finance and Quarterly External Debt Statistics/SDDS. 
Prior to the global crisis Turkey's growing current account deficit was largely financed by long-term loans and FDI inflows. However, FDI inflows were mainly directed towards non-tradable services sectors such as financial intermediation and transport, storage and communication, with limited potential to generate export revenues. The financing structure of Turkey's current account deficit changed dramatically after the crisis. Large short-term inflows from advanced economies, driven by the abundance of cheap money and carry-trade opportunities, have accounted for the bulk of inflows over the past two years (Figure 6A). In particular inflows into the government bond market and short-term loans, mainly channelled through the banking sector, increased sharply. Part of these inflows was absorbed through the build-up of reserve assets by the CBRT to contain currency appreciation. As concerns over the sovereign debt crisis in the euro area intensified and foreign banks started deleveraging in the second half of 2011, capital inflows slowed markedly. The resulting financing gap was partly closed by a drawing down of foreign assets by domestic banks and sales of foreign exchange reserves by the CBRT. Besides official flows, unrecorded exports and capital inflows captured in the balance of payments' net errors and omissions funded around one sixth of the current account gap in $2011{ }^{4}$ However, over the course of 2011 and into 2012 the financing side of the current account showed signs of improvement and FDI inflows increased markedly, rising from US\$ 9 billion in 2010 to US\$ 15.9 billion in 2011.

As the financing structure of the current account worsened, the external debt trended upwards again after the crisis, mainly driven by short-term liabilities (Figure 6B). Research generally shows a positive relationship between external debt (and in particular short-term debt) and the probability of financial crisis. ${ }^{5}$ These results are confirmed by recent OECD analysis looking at the relationship between the composition of external assets and liabilities and the likelihood of banking crisis and contagion risk (Ahrend and Goujard, 2011). This study finds that debt bias (the share of debt in total liabilities), shortterm bank debt - mainly through increased contagion risk - and currency mismatch between external assets and liabilities are positively related to the risk of financial crisis. Compared to the situation prior to the crisis, Turkey's position with respect to all three indicators has deteriorated (Table 1). In addition, the currency mismatch measure might underestimate Turkey's true exposure to a sudden and sharp depreciation as foreign currency loans by domestic banks are not included. About $30 \%$ of total loans to the non-financial sector are denominated in foreign currency (CBRT, 2011). Taking these loans into account, the net foreign currency liability exposure of the non-financial corporate sector was about $\$ 125$ billion (16\% of GDP) in the first quarter of 2012 (Figure 6C), pointing to significant vulnerability to an exchange rate shock. Besides, the net foreign currency exposure of the public sector stands at about $6 \%$ of GDP, whereas the CBRT and the household sector hold long positions in foreign currency of about $7 \%$ and $8 \%$, respectively. The financial sector's net exposure is close to zero (CBRT, 2011). Reserve assets reduce the probability of a financial crisis according to the OECD study, albeit with decreasing marginal effectiveness. Reserve assets increased somewhat after the crisis but official reserves are somewhat lower than peer economies' in terms of months of imports of goods and services and as a share of broad money and short-term debt (Figure 6D).

4. Theses flows are usually attributed to "under-the-mattress" savings, unofficial exports mainly to neighbouring economies, unrecorded tourism income and capital inflows related to the restructuring of public receivables (JP Morgan, 2011) or to political instability in the MENA region.

5. See e.g. Radelet and Sachs (1998), Rodrik and Velasco (1999) and Rogoff (1999, 2011). Moreover Blanchard, Das and Faruquee (2010) show a positive correlation between short-term debt and output losses in emerging markets during the crisis. 
$\mathrm{ECO} / \mathrm{WKP}(2012) 63$

Table 1. Indicators of external financing structure

\begin{tabular}{|c|c|c|c|}
\hline & 2002Q4 & 2007Q4 & 2012Q1 \\
\hline Debt bias $^{1}$ & $87.7 \%$ & $51.7 \%$ & $56.6 \%$ \\
\hline Short-term debt ${ }^{2}$ & $10.1 \%$ & $11.4 \%$ & $14.0 \%$ \\
\hline Currency mismatch ${ }^{3}$ & $-27.2 \%$ & $-9.0 \%$ & $-14.4 \%$ \\
\hline Reserve assets as \% of GDP & $11.4 \%$ & $10.3 \%$ & $11.6 \%$ \\
\hline
\end{tabular}

1 Debt in \% of total liabilities.

2 Short-term liabilities to BIS banks (consolidated) in \% of total liabilities.

3 Difference between foreign currency denominated assets and liabilities as a share of GDP. All foreign assets are assumed to be denominated in foreign currency, whereas FDI and portfolio equity liabilities are assumed to be denominated in domestic currency.

Source: Central Bank of the Republic of Turkey; World Bank, IMF, BIS, OECD Joint External Debt Hub; Undersecretary of Treasury; OECD Economic Outlook Database.

\section{How does the current account deficit compare to benchmarks?}

An important question is to what extent Turkey's current account deficit is excessive. To explore this issue, one needs to establish benchmarks. Two standard ways of doing so are to look at the sustainability of the net external asset position or to estimate equations which relate the current account in the medium term to fundamental determinants of saving and investment. Results from both approaches are described below and details can be found in Röhn (2012.)

\section{External sustainability approach}

The external sustainability approach rests on simple accounting, using balance of payments identities. The derived current account benchmark ensures that the net foreign asset position remains stable at some (arbitrary) level. A standard choice for this level is the currently observed net foreign asset position. Besides the level, this approach only requires assumptions about real GDP growth and inflation. Calculations of this sort show that, assuming 5\% real GDP growth and inflation (measured by the GDP deflator), similar to the assumptions in Turkey's 2012-14 Medium Term Programme, a stable net foreign asset position at the current level (2012Q1) of minus 48\% of GDP is consistent with a current account deficit of $5.4 \%$ of GDP. ${ }^{6}$ This is well below recently observed levels. Even if real GDP growth of $7 \%$ is assumed, the stabilising current account deficit would move only to $6.3 \%$ of GDP.

Alternatively, it might be more relevant to consider stabilising the gross external debt position as FDI and other equity liabilities are generally not considered to compromise sustainability. In this case it is necessary to adjust the current account for non-debt-creating flows. Under the baseline of 5\% real GDP growth and inflation, stability of the gross external debt ratio at the latest observed level of $40 \%$ (2012Q1) of GDP is obtained with an adjusted current account deficit of $4.7 \%$ of GDP compared with an observed deficit of $6.3 \%$ in $2012 \mathrm{Q} 1$. Under the alternative assumption of $7 \%$ real GDP growth, the benchmark would be $5.4 \%$ of GDP.

\section{Macroeconomic balance approach}

Estimations relating the current account to fundamental determinants of saving and investment show that its deterioration after 2001 can be partly explained by higher net oil imports, strong credit growth and a worsening of the terms-of-trade and of the net asset position. Based on assumptions about medium-term values for all saving and investment determinants, estimates of current account norms range between 3\%

6. All calculations in this section assume a contribution of net errors and omissions to the financing of the current account deficit of $1 \%$ of GDP, consistent with historical averages. 
and $4 \%$ of GDP depending on the exact empirical specification. ${ }^{7}$ This is broadly in line with previous findings for Turkey, which are in the range of 2.5\%-5\% of GDP (IMF, 2010, Bussière et al., 2010, Medina et al., 2010). The analysis, however, also shows that saving and investment determinants only explain a small part of the deterioration after 2001. The difference between the estimated and actual current account appears to partly reflect real exchange rate appreciation and hence competitiveness losses as well as differences in the cyclical position between Turkey and the rest of the world.

\section{Policy options to reduce the current account deficit and inflation}

\section{Monetary policy}

Like many other emerging economies with an open capital account, Turkey faces the complex task of taming inflationary pressures without attracting surges in short-term capital inflows. On the one hand, these inflows fuel domestic credit growth, thereby counteracting the intended monetary tightening. On the other hand, they push up the exchange rate, hampering competitiveness. Striking the right balance in the face of this "impossible trinity" - or "trilemma" - remains the key challenge for Turkey's monetary policy in the short to medium term.

Between the crises of 2001 and 2008-09, monetary policy developed gradually into a fully-fledged inflation targeting framework with the short-term interest rate as the main policy instrument (OECD, 2008). In order to reduce high inflation and improve credibility, the CBRT kept real interest rates high in international comparison. This brought down annual inflation from above $70 \%$ to below $10 \%$ between 2001 and 2005. However, high real interest rates, together with reforms to strengthen the resilience of the banking sector and structural reform progress in other areas, attracted strong capital inflows, fuelling real exchange rate appreciation, despite a substantial build-up in foreign reserves. This approach therefore entailed competitiveness losses and a widening current account deficit. In effect, in dealing with the trilemma, Turkey moved towards higher monetary independence and capital openness at the expense of exchange rate stability (Cortuk and Singh, 2011).

In late 2010, Turkey's monetary policy shifted towards a more unorthodox mix, putting more weight on exchange rate developments, credit growth and rebalancing of demand. Faced with short-term capital inflows and accelerating credit, the CBRT first responded with sterilised foreign exchange purchases to stem nominal appreciation and then with hikes in unremunerated reserve requirements differentiated by maturity and currency denomination. The policy rate (the one-week repo rate, which became the policy rate in May 2010) was not raised but the interest rate corridor (difference between overnight $(\mathrm{O} / \mathrm{N})$ borrowing and lending rates) was widened by lowering the borrowing rate with the aim to increase interest rate volatility at the lower end so as to discourage short-term inflows (Figure 7). Credit decelerated more markedly after measures were taken by the banking regulator and supervisor (BRSA) in June 2011 (see below) and capital inflows abated due to heightened global financial turmoil. In August the policy stance shifted in the wake of a sharply depreciated nominal exchange rate and some evidence of a domestic slowdown. The policy rate was cut from $6.25 \%$ to $5.75 \%$, the interest corridor narrowed, reserve requirements on foreign exchange deposits lowered and the CBRT engaged directly in foreign exchange sales, leading reserve assets to fall by about $\$ 7$ billion between July and October. Faced with sharply rising inflation, which was partly due to pass-through effects from the nominal deprecation of the lira, the CBRT changed gear once again in October. The $\mathrm{O} / \mathrm{N}$ lending rate was raised to $12.5 \%$ and the CBRT repeatedly

7. The notion of a current account norm is somewhat misleading as some determinants entering the estimations are "undesirable" fundamentals such as the oil import bill and the fiscal deficit. Thus, all else equal, a more energy inefficient economy or spendthrift government would imply a lower norm for the current account balance. Norm estimates therefore rather summarise average current account tendencies given reasonable assumptions about medium-term developments of the fundamentals. 
provided less liquidity through the one-week repo facility, which caused the market rate to jump. This tighter monetary policy stance was broadly maintained until mid-2012, despite a mostly technical cut of the $\mathrm{O} / \mathrm{N}$ lending rate to $11.5 \%$ in late February 2012 . With inflation declining, the CBRT allowed the market rate to fall to about $6 \%$ since then but kept the main parameters of the monetary regime unchanged.

Figure 7. A new monetary policy regime
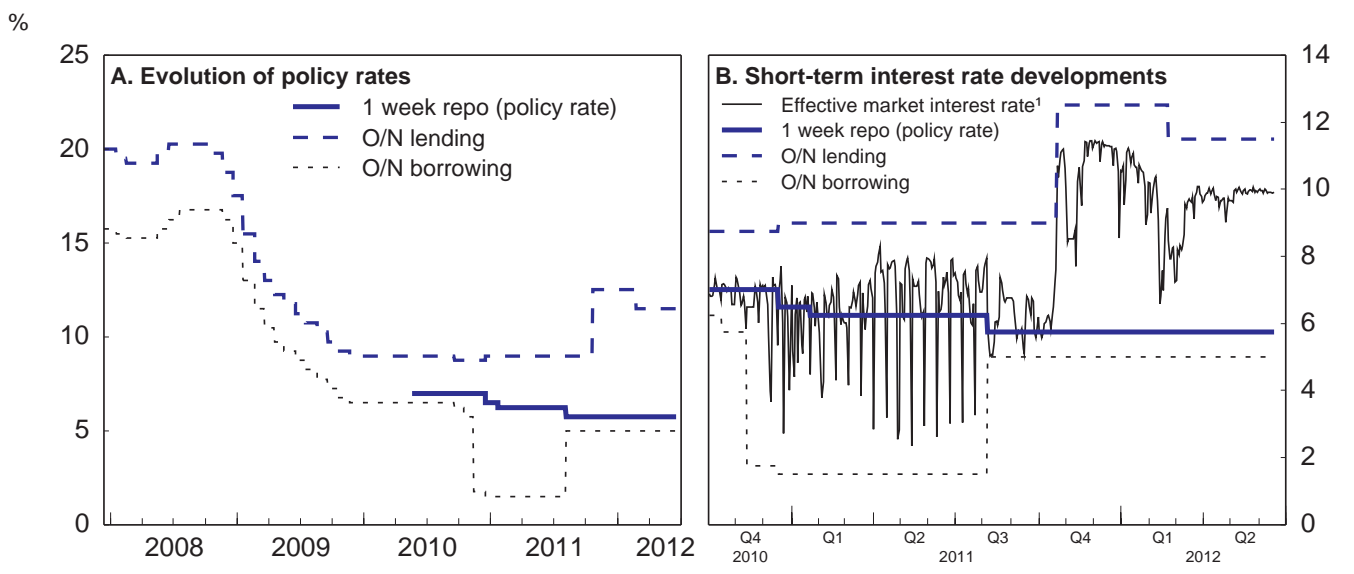

1. Overnight repo rate at the Istanbul Stock Exchange.

Source: Central Bank of Republic of Turkey.

The unconventional monetary policy mix undertaken by the CBRT has to be seen against the backdrop of the constrained environment under which monetary policy is operating and of recent policy discussions about a broader set of monetary policy objectives besides price stability (Blanchard et al., 2010), including an exchange rate goal in the case of emerging economies (Ostry et al., 2012). However, the early record of the new policy regime is mixed. On the positive side, it has contributed to the necessary depreciation of the Turkish lira, in particular between end-2010 and mid-2011, while helping to contain exchange rate volatility. This in turn has facilitated the ongoing rebalancing of growth from domestic to external demand.

However, the policy mix did not deliver low and stable inflation. After falling to a historic low of $3.99 \%$ in March 2011, consumer price inflation rose sharply and reached $10.4 \%$ in December 2011, far above the CBRT's (time-varying) 5.5 $\pm 2 \%$ target, and remained in high in the first half of 2012 (Figure 8A). The CBRT estimates that tax hikes on tobacco products contributed 1.1 percentage points and unprocessed food prices added another 2 percentage points to end-year inflation, although part of the latter should be considered as a contribution to trend inflation. Sizeable adjustments in administered prices, mostly for energy, in October 2011, also fuelled inflation. Core inflation, however, also started to veer up in late 2010 and exceeded $8 \%$ by early 2012 (Figure 8C). The CBRT estimates that increased import prices (in foreign currency), notably for energy, and sharp nominal depreciation have contributed a further 5 percentage points to the inflation surge in 2011. Spare capacity, at the same time, was rapidly diminishing and could not mitigate these pressures. 
Figure 8. Inflation dynamics

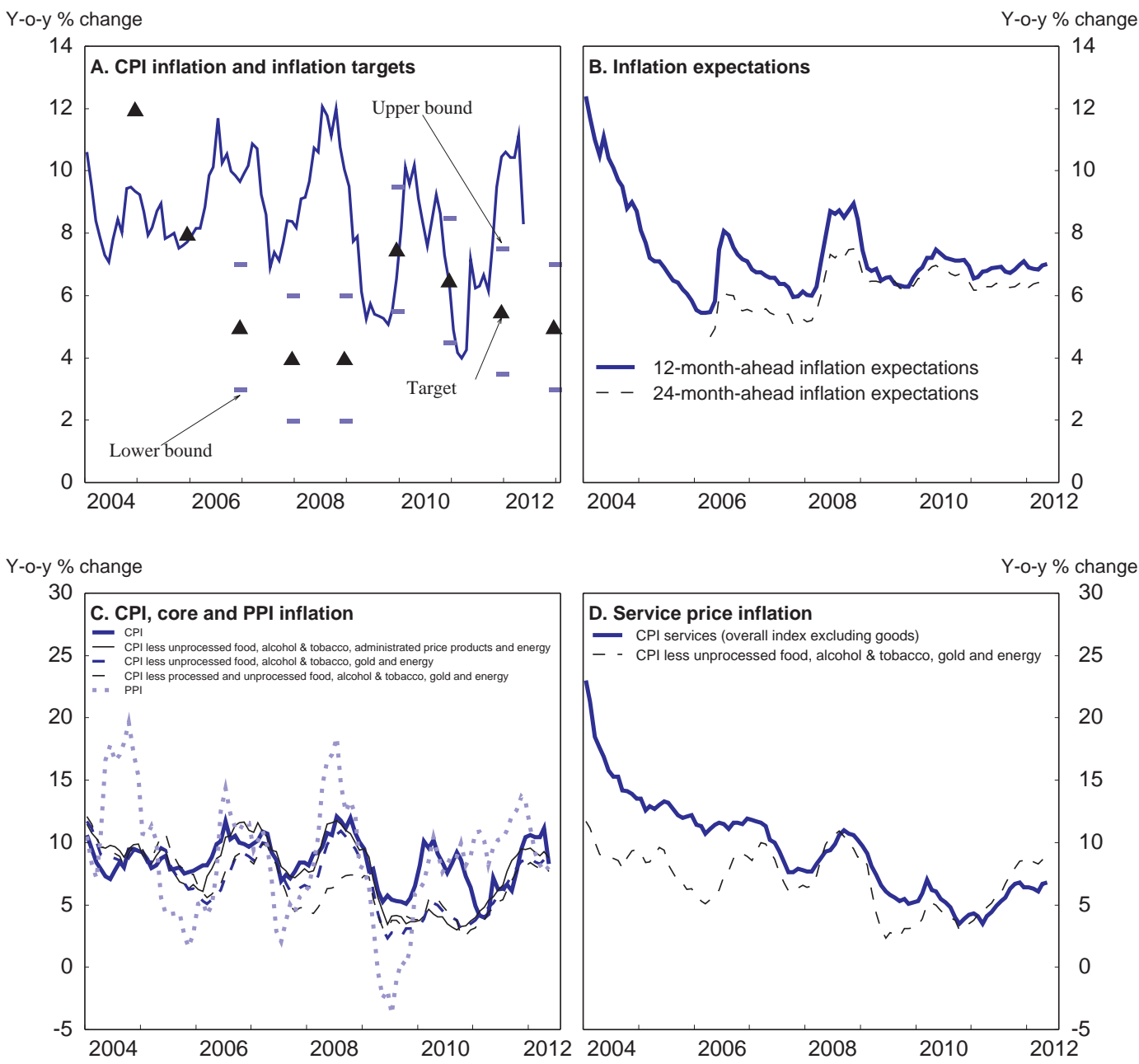

Source: Central Bank of Republic of Turkey; OECD, OECD Economic Outlook database and Eurostat.

Inflation expectations also remain well above the target. After falling steadily between 2002 and 2005 , inflation expectations became more volatile, partly due to repeated overshooting of inflation targets. Since 2010, 12- and 24-month-ahead inflation expectations have stabilised, but above the CBRT's inflation forecast and well above the mid-point of its inflation target (Figure 8B). The CBRT began to set point inflation targets in 2002 and then in 2006 it shifted towards a fully-fledged inflation targeting regime with a medium-term mid-point target and a $\pm 2 \%$ uncertainty band. The inflation target, however, has been breached every year since 2006 except in 2009 and 2010, when the mid-point of the target was temporarily raised to 7.5 and $6.5 \%$ respectively from a previously constant $4 \%$. This has likely contributed to pushing up inflation expectations.

Indeed, empirical analysis conducted for this paper (see Annex A2) suggests that inflation expectations are shaped by: i) past inflation; ii) the inflation target; iii) the exchange rate (through anticipated pass-through effects); $i v$ ) demand conditions; and $v$ ) risk perceptions, partly reflecting the fiscal position and stance. Over the entire January 2003 - April 2012 sample period, the inflation target appears to have a stronger impact on expectations than past inflation. However, the anchoring power of the inflation target appears to have weakened lately. Overall this indicates that to avoid unpleasant feedback loops from inflation expectations to actual inflation, actual inflation needs to align more closely with the target. 
Moreover, persistent inflation differentials with trading partners can erode competitiveness, as they might not be fully compensated by exchange rate depreciation. In any case, chronic depreciation can undermine confidence. Monetary policy's overarching goal should thus remain the reduction of the inflation rate towards its target and eventually towards the levels observed in its main trading partners. To this end, it might be advisable to lower inflation targets in the medium term. For the years 2012, 2013 and 2014 the mid-point of the inflation target has been set at 5\%, well above other OECD countries, where it is usually around $1 \%$ to 3\%. The CBRT (2009) argues that inter alia structural rigidities, the EU convergence process $^{8}$ and measurement problems in price indices related to rapid quality improvements ${ }^{9}$ justify a higher target in Turkey. However, as structural rigidities and convergence effects decline over time and better measurement tools to appropriately capture quality improvements could be developed, a lower inflation target seems achievable in the medium term.

In addition, the complexity of the new regime has given rise to concerns that multiple goals may have reduced the transparency of monetary policy for market participants. ${ }^{10}$ Therefore, stronger communication on the fundamental goals of the new regime and the link between instruments and goals appears advisable. Finally, increased market interest rate volatility, while having helped to deter short-term capital inflows, may be detrimental to investment and may complicate the formation of interest rate expectations which feed into inflation expectations.

Since October 2011 the CBRT appears to have put more weight again on the inflation target and responded to the surge in inflation with a considerable tightening of its monetary stance. Nevertheless, it continues to view the flexibility provided by the new monetary framework as appropriate given that heightened global uncertainty is likely to persist over the medium term and Turkey will continue to face capital flow cycles challenging the conduct of monetary policy. Going forward the monetary authorities expect inflation to gradually fall to about $6.2 \%$ by end-2012, within the target band but still above the target mid-point of 5\% (CBRT, 2012b). The CBRT sees inflation further abating towards 5\% by end-2013. The CBRT has indicated that it might induce tightening if the inflation outlook worsens (CBRT, 2012b). To this end it might be necessary to raise the one-week repo rate and to narrow the interest rate corridor by lifting the $\mathrm{O} / \mathrm{N}$ borrowing rate, provided that domestic economic conditions do not worsen significantly. Once disinflation is on track, the remaining room for manoeuvre should be used to ensure that the real exchange rate stays on a sustainable path and does not depreciate or appreciate excessively. In the event of large capital inflows, sterilised interventions should be used to avoid excessive appreciation, thereby building up reserve assets - which are comparatively low - and helping to mitigate the trilemma trade-offs (Cortuk and Singh, 2011).

8. Inflation differentials vis-à-vis the EU cannot be explained by faster productivity catch-up in the tradable relative to the non-tradable sector in Turkey as would be suggested by the Balassa-Samuelson hypothesis (Lopcu et al., 2012). However, the harmonisation of regulations with the EU does foster price level convergence.

9. Arslan and Ceritoglu (2011) estimate that over 2003-09 about 2.3 percentage points of measured annual consumer price inflation actually correspond to quality improvements.

10. In a March 2012 Survey of domestic and foreign investors, 30\% said that the predictability of the CBRT's actions had diminished recently, while $24 \%$ found that it had increased and $46 \%$ that it had not changed; $46 \%$ felt that the CBRT was sufficiently focused on its inflation objective, whereas $48 \%$ said this was not the case; and 50\% said that CBRT actions would be sufficient to deliver price stability, against $32 \%$ who disagreed (Bloomberg HT, 2012). 


\section{Box 3. Monetary policy recommendations}

- Attaining the inflation target should be given more prominence to bring inflation expectations closer to the target, and, over time, reduce inflation differentials with trading partners.

- During capital inflow surges, appreciation pressures should be countered by sterilised intervention. This would appropriately increase foreign exchange reserves.

- Communication on the fundamental goals of the new regime and the link between instruments and goals should be strengthened. The success of the instruments in achieving these goals should be evaluated.

- Aim to move inflation targets closer to trading partners' in the medium term.

\section{Financial market policy}

Capital inflows have been mainly channelled through the banking sector in Turkey after the crisis, raising the risks of excessively rapid balance sheet expansion and credit growth. Leverage ratios have been increasing after the crisis, but remain low in international comparisons. Turkey has made remarkable progress in reforming its banking sector since 2001, with strong banking regulation and supervision in place. This progress should be consolidated and further enhanced and the authorities have been addressing these risks with both traditional micro-prudential and newly developed macro-prudential tools.

Both sets of tools should continue to be used to manage capital-inflow-driven credit growth cycles, necessitating close cooperation between monetary and financial market authorities to ensure that measures are employed in a coherent manner. The establishment in June 2011 of the Financial Stability Committee (FSC) - which comprises the CBRT, the BRSA, the Undersecretariat of Treasury, the Saving and Deposit Insurance Fund and the Capital Market Board - is a welcome step in this direction, given that the independence of participating institutions is not compromised. The main aim of the FSC is to detect and contain systemic risk in the financial sector.

The robustness of Turkish banks' balance sheets was well preserved during and after the global crisis. Yet, banks' short-term foreign exchange debt rose markedly and their capital ratios declined. The maturity of banks' foreign obligations remains relatively long but declined from an average of 4 years at the end of 2007 to 3.5 years at the end of 2011. Non-financial firms also accumulated sizeable additional foreign currency exposure (see above). In an interim assessment, the ongoing Financial Sector Assessment Programme (FSAP) review of Turkey suggests that banks' capital buffers are sufficient to absorb a shortlived macroeconomic shock, but that strains would be much greater if the shock were protracted (IMF, 2012).

According to the Turkish authorities, however, the sector remains well capitalised and resilient to all reasonable shock scenarios. They nonetheless started to act to increase capital adequacy ratios by limiting dividend pay-outs, and are phasing in new capital charges for maturity mismatches (applicable from July 2012). New regulations on credit risk management are also being prepared and the authorities reconfirmed their intentions to comply with Basel II guidelines in the course of 2012. Work has also started to converge with Basel III.

In June 2011 the BRSA imposed loan-to-value ceilings on housing, commercial and real-estate loans, rescinded the crisis-era easing of prudential standards on loan restructuring and provisioning (after the oneyear extension decided in early 2010), and raised further provisioning requirements and risk weights on loans, together with tighter conditions for the use of credit cards. These measures helped bring credit 
growth back to more sustainable levels and below the 20 to $25 \%$ target. Going forward, monitoring of credit quality risk remains key. Further extensions of credit instruments, in particular those targeted at lowincome groups, should be monitored closely. ${ }^{11}$

Micro- and macro-prudential policies may have limitations when surges in capital inflows are channelled through the non-financial corporate sector. In this case temporary and targeted capital controls, provided they are in line with the provisions of the OECD Code of Liberalisation of Capital Movements, could be considered as an option. While their effectiveness to influence the level of inflows is controversial, well-targeted capital controls can affect the composition of flows towards longer-term maturities or towards "safer" inflows such as FDI and equity inflows (OECD, 2012b and below). Direct capital controls have not been favoured by the authorities to date. In fact, they would conflict with the long-term goal of promoting Istanbul as an international financial centre.

\section{Box 4. Financial policy recommendations}

- $\quad$ As planned, comply fully with Basel II banking supervision guidelines and converge in due course with Basel III guidelines.

- Continue to evaluate countercyclical financial policy measures which have the strongest leverage on aggregate demand, and focus on those.

- Closely monitor the cross-border funding of the non-financial corporate sector and, if and when capital inflows attain a pace incompatible with financial stability, as a last resort consider introducing temporary and targeted capital controls, provided they are in line with the provisions of the OECD Code of Liberalisation of Capital Movements.

- $\quad$ Continue to administer regular banking stress tests, taking into account the full set of conceivable global and domestic shocks, including extreme scenarios of international turbulences and sudden stops.

\section{Fiscal policy}

The general government balance increased markedly between 2002 and 2006. After the countercyclical fiscal stimulus provided during the 2008/09 financial crisis, headline deficits shrank from $6 \%$ of GDP in 2009 to $2.1 \%$ in 2011, according to the latest Pre-accession Economic Programme estimate submitted to the European Commission, which approximates international standards (Government of Turkey, 2012), or $1 \%$ of GDP according to the Medium-Term Programme (MTP), which includes privatisation and one-off revenues (Table 2). The outturn in 2011 was better than in the authorities' MTP, thanks to stronger-than-expected GDP growth and one-off factors. The improvement mainly stemmed from reduced interest payments, strong increases in VAT income, tax hikes on certain imported goods, as well as one-off revenues related to a comprehensive tax amnesty programme. While general government spending decreased as a share of GDP, primary expenditures remained about 3 percentage points of GDP above pre-crisis levels, mainly reflecting higher appropriations for personnel, transfers to social security institutions and capital expenditures. The IMF recently estimated a structural deficit accounting inter alia for transient revenues due to cyclical import growth as well as one-offs related to exceptional bank profits and the tax amnesty (IMF, 2012). The results suggest that the primary structural balance deteriorated since the mid-2000s and stood at $-1 \%$ of GDP in 2011. However, given a low public debt ratio, fiscal sustainability is not jeopardised at current levels of the structural primary balance.

11. Research suggests that periods of strong credit growth are associated with a higher probability of financial crisis (OECD, 2012b, Kaminsky and Reinhart, 1999, Schularick and Taylor, 2012) especially if they involve a loosening of credit standards to risky clients (Mendoza and Terrones, 2008). 
ECO/WKP(2012)63

Table 2. General government balances

\begin{tabular}{|c|c|c|c|c|c|}
\hline \multicolumn{6}{|c|}{ Authorities' estimates, in \% of GDP } \\
\hline & \multirow[b]{2}{*}{ Output gap $^{7}$} & \multicolumn{2}{|c|}{ General government balance } & \multicolumn{2}{|c|}{$\begin{array}{c}\text { Primary general government } \\
\text { balance }\end{array}$} \\
\hline & & Actual & Structural $^{2}$ & Actual & Structural $^{2}$ \\
\hline 1999 & -1.6 & -10.0 & -9.6 & 1.3 & 1.5 \\
\hline 2000 & 1.5 & -9.9 & -10.3 & 3.2 & 2.9 \\
\hline 2001 & -7.8 & -12.6 & -9.5 & 4.9 & 6.7 \\
\hline 2002 & -5.9 & -11.8 & -9.2 & 3.5 & 5.2 \\
\hline 2003 & -5.0 & -8.4 & -6.7 & 4.9 & 5.9 \\
\hline 2004 & -0.6 & -4.4 & -4.5 & 5.9 & 5.8 \\
\hline 2005 & 3.0 & -0.8 & -1.8 & 6.4 & 5.6 \\
\hline 2006 & 5.4 & -0.4 & -2.0 & 5.8 & 4.5 \\
\hline 2007 & 5.6 & -1.7 & -3.5 & 4.2 & 2.7 \\
\hline 2008 & 1.8 & -2.5 & -3.0 & 2.9 & 2.5 \\
\hline 2009 & -7.2 & -6.0 & -3.6 & -0.3 & 1.7 \\
\hline 2010 & -3.1 & -3.3 & -2.3 & 1.2 & 2.1 \\
\hline 2011 & -0.3 & -2.1 & -2.0 & 1.4 & 1.4 \\
\hline 2012 & -0.8 & -2.0 & -1.8 & 1.7 & 1.9 \\
\hline 2013 & -0.2 & -1.7 & -1.6 & 1.8 & 1.9 \\
\hline 2014 & 0.4 & -1.1 & -1.2 & 2.2 & 2.1 \\
\hline
\end{tabular}

1 Percentage difference from potential GDP as estimated by the Ministry of Development.

2 As a ratio of potential GDP.

Source: Government of Turkey (2012).

The present fiscal stance is broadly appropriate and should remain tight. Given the trilemma faced by monetary policy, fiscal policy may need to play a more active countercyclical role and additional discretionary tightening may be required. In particular, in cyclical upturns such a tighter stance would restrain domestic demand and hence inflationary pressures and allow the CBRT to keep the interest rate lower than otherwise, thereby containing interest-rate-elastic capital inflows. This would also allow building up sufficient buffers to counteract a possible capital flow reversal and provide a further impetus to domestic saving. ${ }^{12}$ A particular focus should be on expenditure restraint, and a multi-year spending ceiling could help preserve a tight fiscal stance in case of revenue surprises.

The power of fiscal action should, however, not be exaggerated. The general government sector is relatively small and so are fiscal multipliers (general government primary expenditures are about $33 \%$ of GDP (OECD, 2010)). Fiscal restraint can therefore only partly compensate for private sector exuberance, especially during periods of strong capital inflows. In addition, over the longer run spending needs remain large in areas such as education, social services and physical infrastructure and room needs to be created for such additional spending through savings in existing expenditures (OECD, 2008). The ongoing shift to performance-based budgeting should help identify and exploit latent efficiency gains. At the same time, tax collection is improving and extra revenues can be expected if further progress is made in the formalisation of the economy and these revenues should be saved. Hence fiscal prudence is in order, lest the authorities find themselves forced to pro-cyclically tighten the fiscal stance in a possible cyclical downturn.

In this context, it is crucial to preserve a prudent fiscal stance which takes into account the full range of cyclical budget items. The new methodological approach suggested by the IMF is an interesting step in that direction. While the authorities have reservations regarding some aspects of this methodology and note that there is no agreement in the literature on how to calculate the structural fiscal balance and transient revenues (IMF, 2012), there is no alternative, comprehensive, official Turkish estimate of the cyclical

12. Ricardian equivalence, which suggests that changes in public saving will be offset by changes in private saving, does not seem to hold for Turkey (Akbostanci and Tunc, 2001, World Bank, 2012), in line with research for other OECD countries (e.g. Röhn, 2010). 
component of fiscal balances. In addition to monitoring general government accounts according to international standards, progress in this area would require further technical investigations. A Fiscal Policy Report (similar to the central bank's Inflation Report) encompassing all quasi-fiscal institutions and containing a full set of cyclical adjustments could be published to improve fiscal transparency. In a subsequent step, although the Medium-Term Programme provides an anchor for fiscal policy, the introduction of a permanent fiscal rule could be considered, drawing on earlier government efforts to develop a quantitative fiscal rule permitting the operation of automatic stabilisers (see OECD, 2010). An independent Fiscal Council, along the lines of those existing in a number of OECD countries, could be established to carry out these tasks.

In this context, Turkey's enduring shortcomings in fiscal transparency according to international standards should be remedied. Fiscal accounts at the general government level are not yet timely (OECD, 2010). Although welcome progress has been made on the major components of these accounts, notably through direct data reporting by local governments and social security institutions to the central government, standard general government accounts become available only with very long lags and are not yet fully compliant with international standards (OECD, 2010). Different general government accounting methodologies continue to be used across economic agencies. The financial balances and debt of a range of quasi-fiscal institutions are also not yet part of a systematic monitoring and reporting system. The prospective financial costs of the expanding social security system also call for close scrutiny, against alternative scenarios of growth, employment, revenue collection and pension and health spending. Such scrutiny is particularly important as the ongoing demographic window will close in about a decade, and the old-age dependency ratio will start to increase rapidly, entailing growing ageing costs.

\section{Box 5. Fiscal policy recommendations}

- $\quad$ The present fiscal stance is broadly appropriate and it should remain tight, not least to preserve room for action were the world economy to weaken. If warranted, stand ready to tighten the fiscal stance more.

- Long-term financial balances of the social security system should be investigated with the help of alternative scenarios of growth, employment, revenue collection, and pension and health spending.

- Improve fiscal data at general government level, on a unified accounting basis according to international standards. Publish these accounts at quarterly frequency.

- $\quad$ Adopt a general government spending ceiling within a longer-term fiscal framework. This would help avoid pro-cyclical loosening in case of positive revenue surprises.

- $\quad$ Publish a regular Fiscal Policy Report (similar in format to the central bank's Inflation Report) encompassing all major quasi-fiscal institutions and containing a full set of cyclical adjustments.

- An independent fiscal council could be established, in line with OECD best practices. It could monitor fiscal performance, participate in the design of a fiscal framework, develop alternative methodologies for estimating the cyclical sensitivity of revenues and publish the Fiscal Policy Report.

\section{Policies to increase household saving and to channel them into productive uses}

While the single most important reform area to increase household saving is to increase labour force participation and employment in the formal sector (Gönenç et al., 2012), other policies can help increase the level of savings or channel existing savings into the financial system and hence allocate them to productive investment. 
Awareness of the need to save for the future appears low in Turkey and most savings are either held outside of the financial system in low-yielding investments (gold, jewellery, "under the mattress"), in real estate, including secondary residences, or in a limited variety of financial products (deposits, government securities) (World Bank, 2012). Informality is likely to be one of the key reasons for holding savings outside the financial sector. Thus, reducing informality would also contribute to an increased channelling of household (and corporate) savings through the well-developed banking sector, as demand for informal, unregistered and anonymous assets would be reduced. But raising awareness of the benefits of saving and improving financial literacy can also have important benefits (van Rooij et al., 2012). In this context, the CBRT has recently progressively raised the share of gold that may be held to meet Turkish Lira reserve requirements from $10 \%$ to $30 \%$, providing additional incentives for banks to channel household gold savings into the financial sector.

In addition, remaining tax distortions between different investment vehicles should be eliminated. Until recently investment in mutual funds and exchange traded funds was subject to a withholding tax whereas investment in individual stocks is tax free. This created disincentives both for suppliers of funds to increase product variety and for investors with insufficient knowledge to invest in individual stocks to participate in the stock market through mutual or exchange traded funds. In May 2012, a government decree was passed which exempts mutual funds with an equity share above $75 \%$ from the withholding tax.

A voluntary private pension saving scheme was established in 2003 and has grown rapidly since, but it is still small as a share of GDP compared to other OECD countries. It is characterised by a relatively high rate of early withdrawals, high operational costs (probably due to still insufficient economies of scale), and portfolios highly skewed towards government bonds. Until recently a tax credit was granted, but in June 2012 the government legislated that this tax incentive will be replaced by a direct government contribution to the pension scheme of $25 \%$, capped the annual gross minimum wage. Since this incentive is independent from declared household income, the new system has a higher coverage and the authorities expect a considerable boost to household saving. Saving could also be raised through other tax-preferred mandatory or voluntary private saving schemes unrelated to pensions such as education-savings accounts and life insurance contracts. OECD research (OECD, 2007) shows that tax-preferred saving accounts can create additional saving but the efficiency of the system crucially depends on the participation of middleincome households. The potential to generate additional saving should in both cases be weighed against fiscal costs. Moreover, retirement benefit reform can boost private saving (Attanasio and Brugiavini, 2003). In Turkey early retirement benefits should be made more actuarially neutral and health insurance contributions for early retirees could be introduced (OECD, 2012a). However this effect is likely to be temporary as in the long run, the additional amount saved during the working period should at least partly be offset by lower saving in retirement (Kerdrain et al., 2010).

In this context, it would be useful to publish household accounts as part of the National Accounts on a timely basis and in line with international accounting standards. This would increase transparency, facilitate a better monitoring of household saving behaviour and help analyse the success of particular reform efforts.

\section{Policies to improve the financing of the current account and decrease financial vulnerability}

Recent OECD work (OECD, 2012b) investigated how structural policies can improve the financing structure of the current account and thereby reduce the risk of financial crisis. Findings relevant for Turkey suggest that:

- Restrictive regulations on FDI and more generally strict product market regulations increase financial vulnerability through a bias towards external debt. A previous Economic Survey (OECD, 2008) and recent OECD research (Kalinova et al., 2010) show that Turkey has made 
considerable progress in reducing formal restrictions on FDI inflows. According to the OECD FDI restrictiveness indicator, Turkey's legislation is less restrictive than the OECD average and much less so compared to non-OECD countries. Some room for improvement exists in reducing foreign equity limits, and restricted sectors include transport, media, business services and in particular the real estate sector. A larger effect on FDI inflows is likely to result if the overall business environment and product market regulations are improved. Moreover, reforms that strengthen the competitiveness of the tradable sector are likely to attract more FDI inflows into this sector thereby generating export revenues or reducing import bills.

- Tax systems that favour debt over equity finance bias corporate financing towards debt, including external debt through higher tax deductibility of interest payments compared to dividends or capital gains. High corporate income tax (CIT) rates could also discourage FDI inflows. In Turkey, the CIT rate has been lowered from $30 \%$ to $20 \%$ in 2006 and is below the OECD average. A further shift away from CIT towards indirect taxes, while generally also associated with growth-enhancing effects (Arnold, 2008), appears difficult in Turkey's current circumstances, given the already heavy bias of tax revenues towards indirect taxes.

- While there is some evidence that stricter domestic banking supervision increases borrowing from foreign banks including short-term borrowing by taking advantage of regulatory arbitrage, overall stricter financial oversight is found to reduce investor-sentiment driven capital flow reversals. In addition, a less leveraged banking sector and lower credit/deposit ratios would reduce the risk of contagion-driven crises. More transparent financial markets are less affected by capital outflows in response to investor-sentiment driven capital flow reversals. Turkey scores well compared to other OECD and emerging countries in all of these indicators. However, capital adequacy ratios have been trending down and credit-to-deposit ratios increased after the crisis. These developments need to be monitored closely and the recent measures to increase capital adequacy ratios are welcome.

- While there is only weak evidence that capital controls can influence the level of inflows, strong evidence exists that differentiated capital controls can influence the structure of external liabilities. In particular, the OECD study finds that introducing restrictions on inflows from credit operations while removing them from FDI and equity inflows may reduce external bank debt by as much as 20 percentage points as a share of GDP. Such an approach would also likely improve the currency mismatch in the liabilities position as debt liabilities are often denominated in foreign currency in emerging markets while FDI and equity liabilities are denominated in domestic currency. Capital controls on credit operations may come at the price of distorting competition between domestic and foreign banks and thus macro-prudential measures might be preferable. The effectiveness of capital controls versus macro-prudential measures is likely to depend on whether capital inflows are driven by domestic (pull) factors or external (push) factors. Macro-prudential measures are likely to be more effective in the case of pull factors. While the Turkish authorities are committed to an open capital account, temporary and transparent capital controls, provided they are in line with the provisions of the OECD Code of Liberalisation of Capital Movements, might be worth considering in the event that a surge in short-term capital inflows threatens financial stability and if other policy instruments have been fully exhausted. 


\section{Box 6. Structural policy recommendations}

- $\quad$ Raise awareness of the benefits of saving for retirement and step up initiatives to increase financial literacy. Reduce further tax distortions between different saving vehicles and consider the introduction of other taxpreferred saving accounts.

- Publish household accounts as part of the National Accounts on a timely basis and in line with international accounting standards and monitor and analyse the saving behaviour of different income groups.

- Strengthen incentives for FDI investment, in particular in the tradable sector, mainly through further improvements in external competitiveness and the business environment.

\section{Conclusions}

Turkey's growth performance over the past decade has been strong. However, it has increasingly drawn on foreign saving on the back of competitiveness losses, so that convergence to high-income countries may be interrupted by a slowdown in capital inflows. At the same time, inflation, while falling substantially in the early 2000s, has frequently overshot targets since 2006 . Putting the growth process on a more balanced and sustainable path requires concerted economic policies. Monetary policy needs to strike a balance between steering inflation down without exacerbating short-term capital inflows. Fiscal and financial policies need to back monetary policy more resolutely when the economy shows signs of overheating. Structural reforms supporting macroeconomic policies are indispensable to durably improve competitiveness and private saving and can help bring down inflation (Gönenç et al., 2012). In addition, policy efforts are required to channel existing savings into more productive uses and improve the financing structure of the current account. 


\section{Bibliography}

Ahrend, R. and A. Goujard (2011), "Drivers of Systematic Banking Crisis", OECD Economics Department Working Paper, No. 902.

Akbostanci, E. and A. I. Tunc (2001), "Turkish Twin Deficits: An Error Correction Model of Trade Balance", Middle East Technical University Economic Research Center Working Paper.

André, C., S. Guichard, M., Kennedy and D. Turner (2007), "Corporate Net Lending: A Review of Recent Trends", OECD Economics Department Working Paper, No. 583.

Arnold, J. (2008), "Do Tax Structures Affect Aggregate Economic Growth? Empirical Evidence from a Panel of OECD Countries", OECD Economics Department Working Paper, No. 643.

Arslan, Y. and E. Ceritoglu (2011), "Quality Growth versus Inflation in Turkey”, CBRT Working Paper, No. $11 / 21$.

Atoyan, R. (2010), "Beyond the Crisis: Revisiting Emerging Europe's Growth Model”, IMF Working Paper, No. 10/92.

Attanasio, O. and A. Brugiavini (2003), "Social Security and Household Saving", Quarterly Journal of Economics, Vol. 118, pp. 1075-1179.

Aydin, F., U. Ciplak and E. Yücel (2004), "Export Supply and Import Demand Models for the Turkish Economy", CBRT Working Paper, No. 04/09.

Aydin, F., H. Saygili and M. Saygili (2007), "Empirical Analysis of Structural Change in Turkish Exports", CBRT Working Paper, No. 07/08.

Baskaya, Y. and T. Hülagü (2011), "Informal-Formal Worker Wage Gap in Turkey: Evidence From A Semi-Parametric Approach", CBRT Working Paper, No. 11/15.

Baskaya, Y., H. Kara and D. Mutluer (2008), "Expectations, Communication and Monetary Policy in Turkey”, CBRT Working Paper, No. 0801.

Baskaya, Y., E. Gülsen and M. Orak (2010), "2008 Hedef Revizyonu Oncesi ve Sonrasinda Enflasyon Beklentileri" (Inflation Expectations before and after the Target Revision in 2008), CBRT Economic Notes, No. 1001.

Baskaya, Y., E. Gülsen and H. Kara (2012), "İletişim Politikası ve Enflasyon Beklentileri” (Communication Policy and Inflation Expectations), CBRT Economic Notes, No. 12/14.

Bayoumi, T., H. Tong and S.-J. Wei (2010), "The Chinese Corporate Savings Puzzle: A Firm-Level CrossCountry Perspective, NBER Working Paper, No. 16432.

Bevilaqua, A., M. Mesquita and A. Minella (2007), "Brazil: Taming Inflation Expectations", Central Bank of Brazil Working Papers Series, No. 129.Blanchard, O., M. Das and H. Faruqee (2010), "The Initial Impact of the Crisis on Emerging Market Countries", Brookings Papers on Economic Activity, Vol. 41, pp. 263-307. 
Blanchard, O., G. Dell'Ariccia and P. Mauro (2010), "Rethinking Macroeconomic Policy", Journal of Money, Credit and Banking, Vol. 42 Supplement.

Blanchard, O. and G.-M. Milesi-Ferretti (2012), “(Why) Should Current Account Balances be Reduced?”, IMF Economic Review, Vol. 60, pp. 139-150.

Bloomberg HT (2012), "Piyasada Merkez Bankasi Algisi Kutuplasiyor" (Polarisation in the Reading of Central Bank Actions by the Market - a Survey), 2 April, http://www.bloomberght.com/haberler/haber/1113637-piyasada-merkez-bankasi-algisi-kutuplasiyor

Bussière, M., M. Ca'Zorzi, A. Chudik and A. Dieppe (2010), "Methodological Advances in the Assessment of Equilibrium Exchange Rates", ECB Working Paper, No. 1151.

Caballero, R. and G. Lorenzoni (2007), "Persistent Appreciations and Overshooting: A Normative Analysis", NBER Working Paper, No. 13077.

CBRT (2009), Central Bank of the Republic of Turkey, Monetary and Exchange Rate Policy for 2010, 10 December.

CBRT (2011), Central Bank of the Republic of Turkey, Financial Stability Report, Vol. 13, November.

CBRT (2012a), Central Bank of the Republic of Turkey, Financial Stability Report, Vol. 14, May.

CBRT (2012b), Central Bank of the Republic of Turkey, Inflation Report 2012-III, July.

Cline, W. and J. Williamson (2011), “The Current Currency Situation”, Peterson Institute for International Economics Policy Brief, No. PB11-18, November.

Cortuk, O. and N. Singh (2011), “Turkey's Trilemma Trade-Offs: Is There a Role for Reserves?”, MPRA Paper, No. 33887.Gagnon, J. (2007), "Productive Capacity, Product Varieties and the Elasticities Approach to the Trade Balance", Review of International Economics, Vol. 15, pp. 285-318.

Government of Turkey (2012), Pre-accession Economic Programme submitted to the European Commission, January, Ankara.

Gönenç, R., O. Röhn, V. Koen and S. Saygili (2012), “Structural Reforms to Boost Turkey's Long-Term Growth", OECD Economics Department Working Paper, No. 987.

Hausmann, R. and R. Rigobon (2003), "IDA in UF: On the Benefits of Changing the Currency Denomination of Concessional Lending to Low-Income Countries", unpublished manuscript, World Bank.

IMF (2010), Turkey: 2010 Article IV Consultation and Post-Program Monitoring, IMF Country Report No. 10/278, IMF, Washington, D.C.

IMF (2012), Turkey: 2011 Article IV Consultation, IMF Country Report No. 12/16, IMF, Washington, D.C.

J.P. Morgan (2011), “Turkey Remains Dependent on Bond Inflows”, Economic Research Note, November 25. 
Kalinova, B., A. Palerm and S. Thomsen (2010), “OECD's FDI Restrictiveness Index: 2010 Update”, OECD Working Papers on International Investment, No. 2010/3.

Kaminsky, G. and C. Reinhart (1999), "The Twin Crisis: The Causes of Banking and Balance-of-Payments Problems", American Economic Review, Vol. 89, pp. 473-500.

Kerdrain, C., I. Koske and I. Wanner (2010), “The Impact of Structural Policies on Saving, Investment and Current Accounts", OECD Economics Department Working Paper, No. 815.

Kesriyeli, M., E. Özman and S. Yigit (2011), "Corporate Sector Liability Dollarization and Exchange Rate Balance Sheet Effect in Turkey", Applied Economics, Vol. 43, pp. 4741-47.

Lopcu, K., A. Burgac and F. Dülger (2012), "Can Productivity Increases Really Explain the Lira Appreciation: Questions for the Central Bank of the Republic of Turkey", Paper prepared for the presentation at the $32^{\text {nd }}$ Annual Meeting of the MEEA, ASSA, January 5-8, Chicago, USA.

Medina, L., J. Prat and A. Thomas (2010), "Current Account Balance Estimates for Emerging Market Economies", IMF Working Paper, No. 10/43.

Mendoza, E. and M. Terrones (2008), "An Anatomy of Credit Booms: Evidence from Macro Aggregates and Micro Data", IMF Working Paper, No. 8226.

OECD (2007), "Encouraging Savings through Tax-Preferred Accounts", OECD Tax Policy Studies, No. 15 .

OECD (2008), OECD Economic Surveys: Turkey, Vol. 2008/14, OECD, Paris.

OECD (2010), OECD Economic Surveys: Turkey, Vol. 2010/13, OECD, Paris.

OECD (2012a), Economic Policy Reforms 2012: Going for Growth, OECD, Paris.

OECD (2012b), "International Capital Mobility: Which Structural Policies Reduce Financial Fragility?", OECD Economic Policy Papers, No. 02.

Ostry, J., A. Ghosh and M. Chamon (2012), "Two Targets, Two Instruments: Monetary and Exchange Rate Policies in Emerging Market Economies", IMF Staff Discussion Note, No. 12/01.

Özlale, Ü. and E. Cunedioglu (2011), “Turkey’s Export Performance I: Weaker Competitiveness, Faster Adaptation", TEPAV Policy Note, No. 201124.

Radalet, S. and J. Sachs (1998), "The Onset of the East Asian Financial Crisis", NBER Working Paper, No. 6680 .

Rodrik, D. (2006), "Industrial Development: Stylized Facts and Policies," unpublished manuscript, Kennedy School of Government (August).

Rodrik, D. and A. Velasco (1999), "Short-term Capital Flows", NBER Working Paper, No. 7364.

Rogoff, K. (1999), “International Institutions for Reducing Global Financial Instability”, Journal of Economic Perspectives, Vol. 13, pp. 24-42. 
Rogoff, K. (2011), “Global Imbalances without Tears”, Speech, March 2011. www.projectsyndicate.org/commentary/rogoff78/English.

Röhn, O. (2010), "New Evidence on the Private Saving Offset and Ricardian Equivalence", $O E C D$ Economics Department Working Paper, No. 762.

Röhn, O. (2012), “Current Account Benchmarks for Turkey”, OECD Economics Department Working Paper, No. 988.

Sarikaya, C. (2004), "Export Dynamics in Turkey”, Central Bank Review, Vol. 4, No. 2, Central Bank of the Republic of Turkey.

Sato, K. (1977), “The Demand Function for Industrial Exports: A Cross-Country Analysis”, Review of Economics and Statistics, Vol. 65, pp. 456-64.

Schularick, M. and A. Taylor (2012), "Credit Booms Gone Bust: Monetary Policy, Leverage Cycles and Financial Crisis, 1870-2008”, American Economic Review, Vol. 102, pp. 1029-61.

van Rooij, M., A. Lusardi and R. Alessie (2012), "Financial Literacy, Retirement Planning and Household Wealth", The Economic Journal, Vol. 122, pp. 449-78.

World Bank (2012), Turkey CEM Synthesis Report: Sustaining High Growth: The Role of Domestic Savings, Report No. 66301-TR.

Yilmaz, G. and R. Gönenç (2008), "How Did the Turkish Industry Respond to Increased Competitiveness Pressures, 1998-2007?”, CBRT Working Paper, No. 08/04. 


\section{Annex A1. The real exchange rate and the current account}

Real exchange rate changes affect the current account mainly through the trade balance. Theoretically, however, the effect on the trade balance is ambiguous. For instance, a real exchange rate depreciation will improve the export value through either increased export volumes or higher export prices (denominated in the home currency) or a combination of both. On the other hand import volumes will generally fall after a depreciation but import prices (denominated in domestic currency) will rise and the effect on the import value is ambiguous. More generally the effect of a real exchange rate change on the trade balance depends on $i$ ) the price elasticities of export and import volumes; ii) the pass-through from the nominal exchange rate and from domestic and foreign prices to import and export prices; and iii) the initial position of the trade balance. The overall effect is thus an empirical question.

Table A1.1. Trade elasticities for Turkey

\begin{tabular}{|c|c|c|c|c|}
\hline Study & Time period & Variables & \multicolumn{2}{|c|}{ Elasticities } \\
\hline & & & Short-term & Long-term \\
\hline \multicolumn{5}{|c|}{ Exports } \\
\hline \multirow{3}{*}{ Aydin et al. (2004) } & \multirow{3}{*}{$1987 q 1-2003 q 4$} & \multirow{3}{*}{$\begin{array}{l}\text { Turkish real GDP } \\
\text { Export price } \\
\text { Unit labour costs }\end{array}$} & 0.4 & 1.9 \\
\hline & & & -0.5 & -1.1 \\
\hline & & & -0.2 & -0.2 \\
\hline \multirow{3}{*}{ Sarikaya (2004) } & \multirow{3}{*}{$1989 q 1-2003 q 3$} & Turkish real GDP & 1.3 & 1.4 \\
\hline & & Real exchange rate (CPI) & -0.7 & 0.6 \\
\hline & & Real wages & 0.4 & -0.8 \\
\hline \multirow{3}{*}{ Aydin et al. (2007) } & \multirow{3}{*}{$1987 q 1-2006 q 4$} & OECD real GDP & \multirow{3}{*}{\multicolumn{2}{|c|}{$\begin{array}{c}1.32-1.45 \\
-0.35--0.09 \\
-0.26--0.18 \\
\end{array}$}} \\
\hline & & Real exchange rate (CPI) & & \\
\hline & & Real exchange rate (ULC) & & \\
\hline \multirow{2}{*}{ Aydin and Eren (2011) } & \multirow{2}{*}{$1997 q 1-2011 q 2$} & \multirow{2}{*}{$\begin{array}{l}\text { Global economic activity index } \\
\text { Real exchange rate (ULC) }\end{array}$} & 4.7 & \\
\hline & & & -0.27 & \\
\hline \multicolumn{5}{|l|}{ Imports } \\
\hline \multirow{2}{*}{ Aydin et al. (2004) } & \multirow{2}{*}{$1987 q 1-2003 q 4$} & Real GDP & 1.2 & 1.99 \\
\hline & & Real exchange rate (CPI) & 0.5 & 0.4 \\
\hline
\end{tabular}

Source: Central Bank of Republic of Turkey.

Empirical studies for Turkey show that export and import volumes are elastic to real exchange rate changes. A real depreciation improves export volumes and reduces import volumes. However, the range of estimated export elasticities is relatively wide (Table A1.1). Moreover, the price elasticity of imports varies according to the type of good, with consumption goods typically having the largest elasticity and intermediate goods the lowest (according to unpublished Treasury estimates). To gauge the overall impact on the trade balance it is necessary to estimate price equations as well. To this end a Turkish trade model, which consists of four equations for the price and volume of exports and imports as described in the previous Economic Survey (OECD, 2010), has been updated and re-estimated. One special feature of this model is that it is augmented with a relative productivity term, following Sato (1977) and Gagnon (2007). This variable aims at capturing non-price competitiveness and other factors explaining international trade such as taste for variety, product differentiation and economies of scale. The intuition is that fast-growing countries are likely to raise the quality of their products and to encourage innovation, improving ceteris paribus their trade balances. The trade equations are estimated as an error correction model and the longrun relations are given below (standard errors in brackets): 
ECO/WKP(2012)63

$$
\begin{gathered}
m g s v=42.17+2.57 * g d p v-0.53 * r p m-1.68 * r p c \\
(0.18) \quad(0.21) \quad(0.45) \\
x g s v=0.13+1.00 * x m k t-0.74 * r p x+0.37 * r p c \\
(0.17) \quad(0.13) \\
(p m g s-p g d p)=1.23-0.65 *(p g d p-p m s h) \rightarrow p m g s=1.23+0.35^{*} p g d p+0.65 * p m s h \\
(0.15) \\
(p x g s-p g d p)=0.99-0.55^{*}(p g d p-p x c) \rightarrow p x g s=0.99+0.45^{*} p g d p+0.55^{*} p x c \\
(0.06)
\end{gathered}
$$

$\begin{array}{cc}\text { adj. } \mathrm{R}^{2} & \text { sample } \\ 0.80 & 1993-2011 \\ & \\ 0.61 & 2001-11 \\ & \\ 0.68 & 1990-2011 \\ & \\ 0.81 & 1990-2011\end{array}$

where $m g s v$ and $x g s v$ are import and export volumes (goods and services), $g d p v$ is Turkish real GDP, $r p c$ is relative productivity defined as average labour productivity divided by the weighted average of Turkey's main trade partners', xmkt is weighted export demand, pmsh is the weighted export price of Turkey's trade partners (denominated in Turkish lira), pxc is the weighted export price of Turkey's main competitors in foreign markets (denominated in the Turkish lira), pgdp, pmgs and pxgs are Turkey's GDP, import and export deflators respectively, $r p m$ is the relative import price $(p m g s-p g d p)$, and $r p x$ is the relative export price $(p x g s-p x c)$. Small letters denote variables in logarithms. The estimated elasticities of the volume equations are broadly in line with previous studies but the export price elasticity is at the upper end of the range. The price equations suggest that import and export prices are mainly determined by foreign prices.

The trade balance is given by:

$\mathrm{TB}_{\mathrm{t}}=\mathrm{PXGS}_{\mathrm{t}}{ }^{*} X G S V_{\mathrm{t}}-\mathrm{PMGS}_{\mathrm{t}}{ }^{*} M G S V_{\mathrm{t}}$

Using equations (1)-(4), it is possible to calculate the elasticity of the trade balance to a change in the nominal exchange rate or domestic price level. The overall elasticity depends on the respective shares of exports and imports in GDP. Using current shares and taking the estimates at face value, a $1 \%$ depreciation of the nominal exchange rate (or equivalently a $1 \%$ reduction in the GDP deflator) would ceteris paribus reduce the trade deficit as a share of GDP by $1.4 \%$ in the long run. 


\section{Annex A2. Empirical analysis of inflation expectations in Turkey}

To better understand the formation and evolution of inflation expectations in Turkey, a reduced-form inflation expectations equation similar to the one presented in Baskaya et al. $(2008,2010)$, Bevilaqua et al. (2007) and CBRT (2012, Box 7.2) was estimated:

$\pi_{t+12}^{e}=\beta_{0}+\beta_{1} \pi_{t-1}+\beta_{2} \pi_{t+12}^{T}+\beta_{3} e r_{t-1}+\beta_{4} i p_{t-2}+\beta_{5} e m b i_{t-1}+\beta_{6} o i l_{t-1}+\epsilon_{t}$

The lag structure of the right-hand side variables is chosen to reflect the latest available information to survey respondents. $\pi_{t+12}^{e}$ is the 12-month ahead CPI inflation expectation (from the Central Bank of the Republic of Turkey (CBRT) survey), ${ }^{13} \pi_{t-1}$ the past month's annual CPI inflation rate to proxy for backward-looking behaviour ${ }^{14}$ and $\pi_{t+12}^{T}$ the 12-month ahead (time-varying) inflation target rate. Monthly inflation targets are constructed by interpolating official end-year inflation targets. Anticipated passthrough effects are captured by annual nominal changes of an exchange rate basket (equally weighted US dollar and euro), er, with a positive value indicating depreciation. Demand pressures are proxied by deviations of the seasonally-adjusted industrial production index, ip, from its trend (calculated using a Hodrick-Prescott filter). The potential influence of risk perceptions on inflation expectations is taken into account by adding a composite risk indicator "EMBI+ Turkey", embi, partly reflecting the fiscal position and stance. Finally, as Turkey imports a large share of the energy it uses, oil prices potentially affect inflation expectations and this is reflected by the inclusion of year-on-year changes of (North Sea crude) oil prices in US dollars, oil. Results from various unit root tests, while partly mixed, generally suggest the presence of a unit root in the time series of embi and hence the first difference of this variable is used in the regressions.

The fit of the model is good as indicated by the high adjusted $\mathrm{R}^{2}$ (Table A2.1). All coefficients have the expected sign, although the oil price coefficient is statistically insignificant. The inflation target appears to play a greater role than past inflation in the formation of inflation expectations - a result that is robust to a range of different combinations of the right-hand-side variables. Moreover, demand conditions, anticipated pass-through effects and risk perceptions also appear to influence inflation expectations. The coefficient of the latter implies that an increase in the EMBI by 100 basis points leads to a rise in inflation expectation by 0.2 percentage points.

To analyse whether the weight of the determinants of inflation expectations has changed over time, rolling regressions with a 36-months window are conducted (Figure A2.1). The results suggest that the role of past inflation remained relatively stable since 2009 with some weakening in the recent past. The jump of the coefficient at the end of 2006 could reflect the fact that at this time inflation overshot the target for the first time since the adoption of an (implicit) inflation targeting regime (see main text). This is consistent with the finding that the weight of the inflation target started to decline around the same time. The coefficients of the exchange rate and risk perceptions have fallen since 2008, while that of industrial production has increased, although some weakening occurred very recently. The only coefficient that has substantially gained weight over time is the intercept, which suggests that inflation expectations remained stable in the recent past, but at a level above the official inflation target.

13. The use of market-based inflation expectations as the dependent variable resulted in partly counter-intuitive results, which may be due to the short time span of the series (available only since September 2009).

14. Results using core inflation instead of headline inflation were broadly similar but led to a reduction in the fit of the regressions. Therefore the results are not reported. 
Table A2.1. Inflation expectations estimation results

OLS estimates

\begin{tabular}{lc}
\hline Variable & Coefficient \\
\hline Constant & 0.122 \\
& $(0.81)$ \\
Past inflation & 0.311 \\
& $(15.23)^{\star \star *}$ \\
Inflation target & 0.726 \\
& $(20.76)^{* * *}$ \\
Exchange rate & 0.028 \\
& $(5.10)^{* * *}$ \\
Industrial production & 0.093 \\
& $(5.16)^{* * *}$ \\
EMBI+ Turkey & 0.002 \\
& $(1.86)^{*}$ \\
Oil price & 0.002 \\
& $(0.71)$ \\
\hline Adjusted $\mathrm{R}^{2}$ & 0.98 \\
Number of observations & 112 \\
Time period & $1 / 2003-4 / 2012$ \\
\hline
\end{tabular}

Notes: The dependent variable is the survey-based 12-months-ahead CPI inflation expectation. T statistics are in parentheses. Newey-West robust standard errors are used. ${ }^{*},{ }^{* *}$ and ${ }^{* * *}$ indicate significance at the $10 \%, 5 \%$ and $1 \%$ level, respectively.

Source: OECD estimates.

Using a panel data set with individual survey participants' expectations over time instead of average expectations as employed in the analysis above, Baskaya et al. (2012) are able to exploit greater variation of the dependent variable. They find a gradual fall of the weight of past inflation since 2010. This could be due to the high volatility of actual inflation or, as stressed by the authors, could signal improved effectiveness of central bank communication at convincing survey participants of the temporary nature of inflation surges. In addition, they find that the CBRT inflation forecast (for 12-month-ahead expectations) and the inflation target (for 24-month-ahead expectations) continue to serve as an anchor for inflation expectations. 
Figure A2.1. Changing impacts on inflation expectations

Coefficient estimates and $95 \%$ confidence intervals from rolling regressions ${ }^{1}$
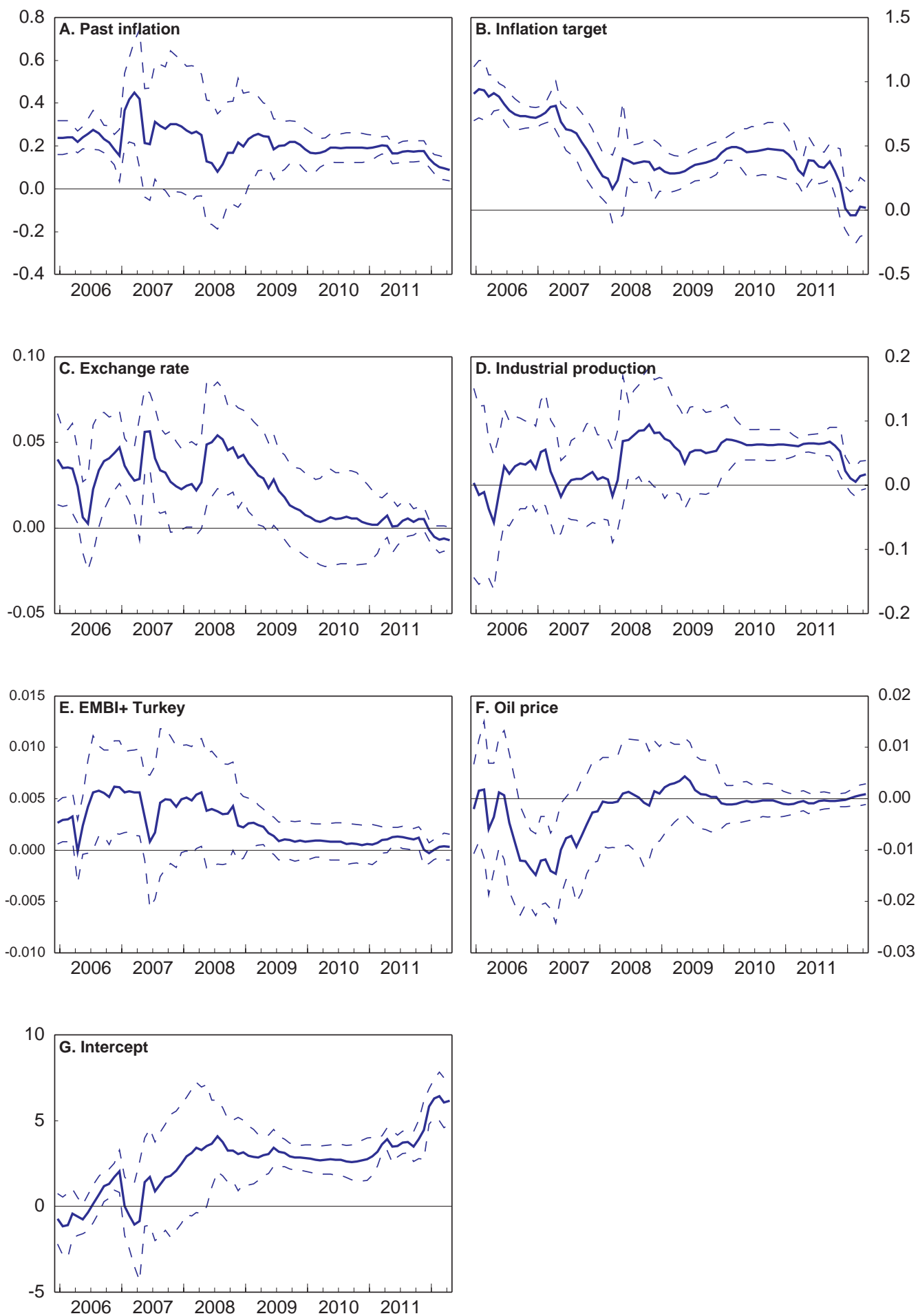

1. Using a 36-month rolling window running to the date marked on the x-axis.

Source: OECD estimates. 


\section{WORKING PAPERS}

The full series of Economics Department Working Papers can be consulted at www.oecd.org/eco/workingpapers/

985. Portugal: Solid foundations for a sustainable fiscal consolidation (September 2012) by David Haugh and Stéphane Sorbe

984. Portugal: Assessing the risks around the speed of fiscal consolidation in an uncertain environment (September 2012) by Stéphane Sorbe

983. The German labour market: preparing for the future (September 2012) by Felix Hüfner and Caroline Klein

982. Climate change policies in Germany: make ambition pay (September 2012) by Caroline Klein

981. Restarting the growth engine in Finland (September 2012) by Henrik Braconier

980. Import Competition, Domestic Regulation and Firm-Level Productivity Growth in the OECD (September 2012) by Sarra Ben Yahmed and Sean Dougherty

979. Non-Parametric Stochastic Simulations to Investigate Uncertainty around the OECD Indicator Model Forecasts

(August 2012) by Elena Rusticelli

978. Measuring GDP Forecast Uncertainty using Quantile Regressions (July 2012) by Thomas Laurent and Tomasz Kozluk

977. Implications of output gap uncertainty in times of crisis (July 2012) by Romain Bouis, Boris Cournède and Ane Kathrine Christensen

976. Avoiding debt traps: financial backstops and structural reforms (July 2012) by Pier Carlo Padoan, Urban Sila and Paul van den Noord

975. Sluggish productivity growth in Denmark: the usual suspects? (July 2012) by Müge Adalet McGowan and Stéphanie Jamet

974. Towards green growth in Denmark: improving energy and climate change policies (July 2012) by Stéphanie Jamet

973. An Analysis of Productivity Performance in Spain before and during the Crisis: Exploring the Role of Institutions

(June 2012) Juan S. Mora-Sanguinetti and Andrés Fuentes

972. Europe's new fiscal rules

(June 2012) by Sebastian Barnes, David Davidsson and Łukasz Rawdanowicz

971. Credit Crises and the Shortcomings of Traditional Policy Responses

(June 2012) by William R. White 


\section{$\mathrm{ECO} / \mathrm{WKP}(2012) 63$}

970. International Capital Mobility and Financial Fragility

Part 7. Enhancing Financial Stability: Country-specific Evidence on Financial Account and Structural Policy Positions

(June 2012) by Rudiger Ahrend and Carla Valdivia

969. International Capital Mobility and Financial Fragility

Part 6. Are all Forms of Financial Integration Equally Risky in Times of Financial Turmoil? Asset Price Contagion during the Global Financial Crisis

(June 2012) by Rudiger Ahrend and Antoine Goujard

968. International Capital Mobility and Financial Fragility

Part 5. Do Investors Disproportionately Shed Assets of Distant Countries under Increased

Uncertainty? Evidence from the Global Financial Crisis

(June 2012) by Rudiger Ahrend and Cyrille Schwellnus

967. International Capital Mobility and Financial Fragility

Part 4. Which Structural Policies Stabilise Capital Flows when Investors Suddenly Change their

Mind? Evidence from Bilateral Bank Data

(June 2012) by Rudiger Ahrend and Cyrille Schwellnus

966. International Capital Mobility and Financial Fragility

Part 3. How do Structural Policies affect Financial Crisis Risk? Evidence from Past Crises across $O E C D$ and Emerging Economies

(June 2012) by Rudiger Ahrend and Antoine Goujard

965. Sustaining Korea's convergence to the highest-income countries

(June 2012) by Randall S. Jones and Satoshi Urasawa

964. Achieving the "low carbon, green growth" vision in Korea

(June 2012) by Randall S. Jones and Byungseo Yoo

963. Promoting social cohesion in Korea

(June 2012) by Randall S. Jones and Satoshi Urasawa

962. Housing price and investment dynamics in Finland

(May 2012) by Christophe André and Clara Garcia

961. Improving health outcomes and system in Hungary

(May 2012) by Mehmet Eris

960. Towards a more inclusive labour market in Hungary

(May 2012) by Rafał Kierzenkowski

959. Ensuring stability and efficiency of the Hungarian financial sector

(May 2012) by Olena Havrylchyk

958. Ensuring debt sustainability amid strong economic uncertainty in Hungary

(June 2012) by Pierre Beynet and Rafał Kierzenkowski 